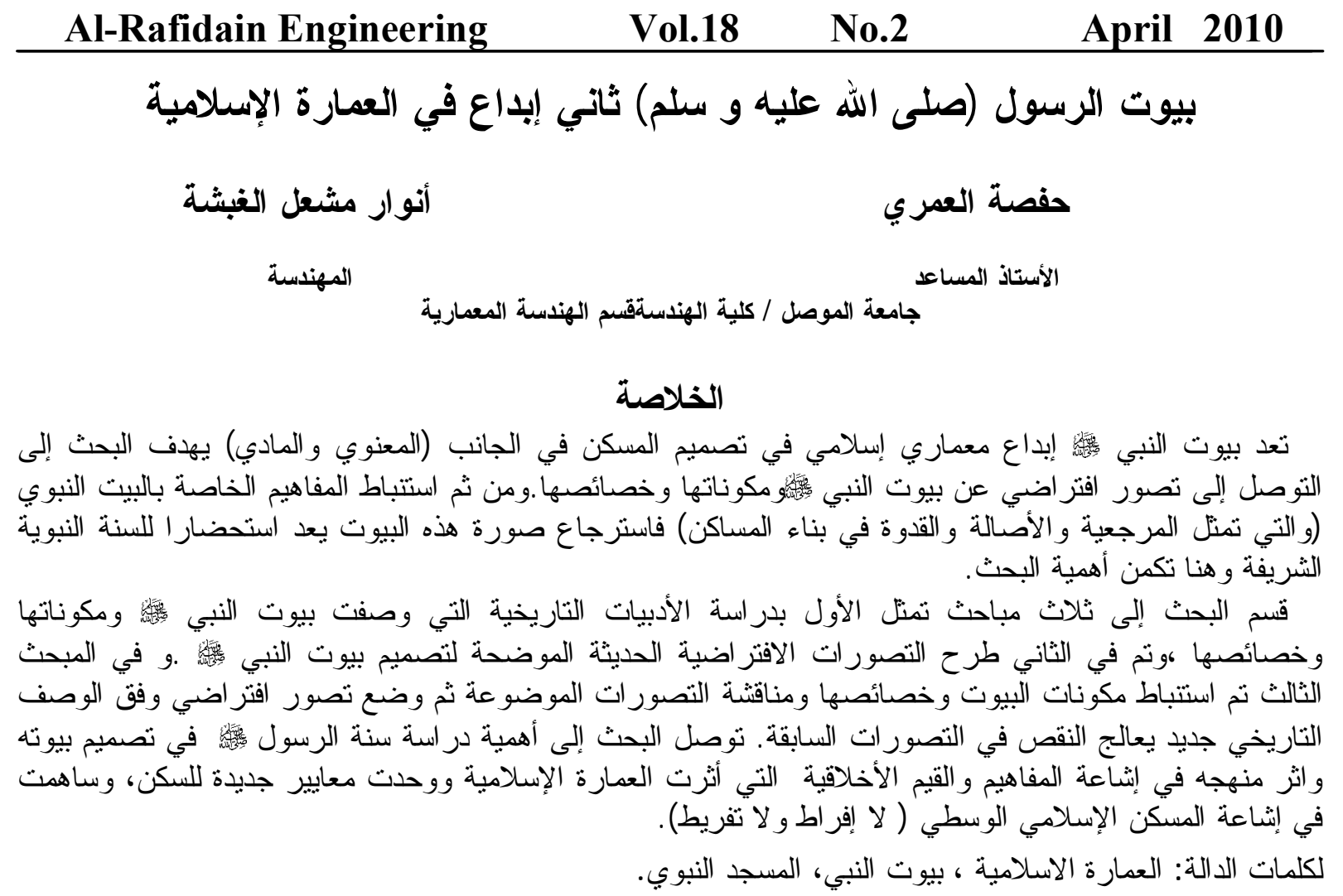

\title{
The homes of the Prophet (may Allah bless him and grant him salvation) are the second innovation of Islamic Architecture
}

\section{Hafsa Ramzi Alomari}

Assistant professor

E - mail : hafsa_alomari2004@yahooCom

\section{Anwar Meshal}

Architect

E-mail:an.muslima@yahoo.com

Mosul University / Collage of engineering/ Architectural department

\begin{abstract}
The homes of the Prophet (觖) are innovation of Islamic architectural in home design in the (mental and physical) sides. Research aims to find a scenario for the homes of the Prophet (被), their components and their properties. The development of the Prophet's House concept represents the reference and the original and the example in the construction of housing. Return of the image of the house is evoke for the Sunni of the Prophet Muhammad and here lies the importance of the research. Research has been divided into three parts, the first study the historical literature that described the homes of the Prophet (敏) and their components and characteristics. The second clarify the modern scenarios of the Prophet houses design( ( the scenarios according to the literatures . then in the third topic offering a new scenario as described in historical literatures (closer to the real). the research in sure the importance of studying the Sunni of the Prophet (敏) in the design of his homes, which stabilize the morals and spirituals constructive of the house design standards and concepts. To promote Central Islamic housing (not forsake nor excessive)
\end{abstract}

Key word: Islamic Architectural- The Prophet's Houses 
المقدمة

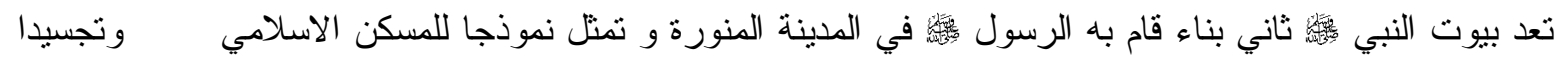

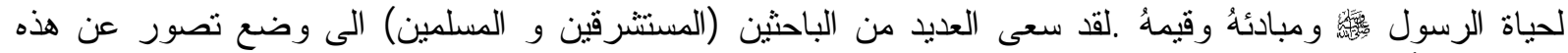

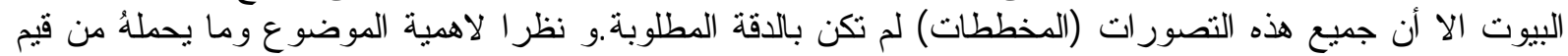

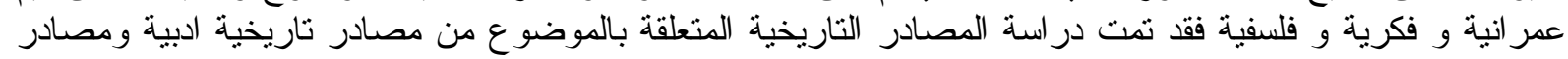

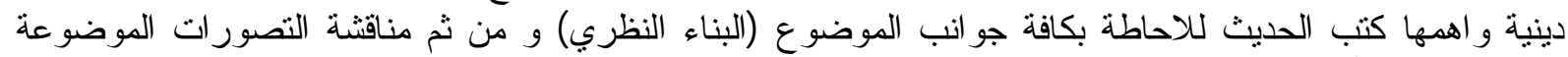

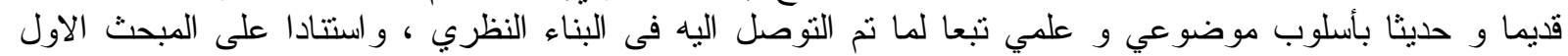

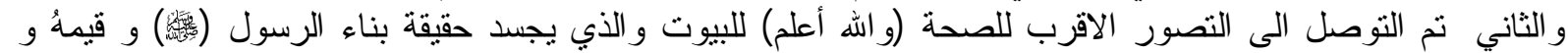

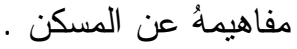

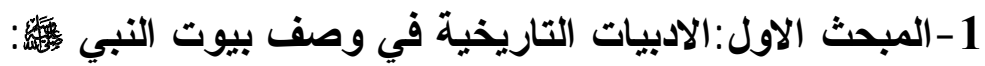

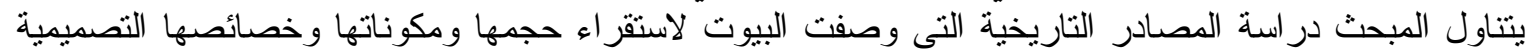
و الثكلية:

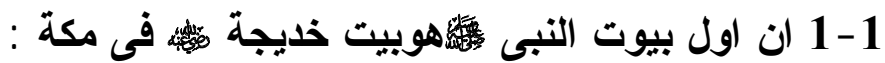

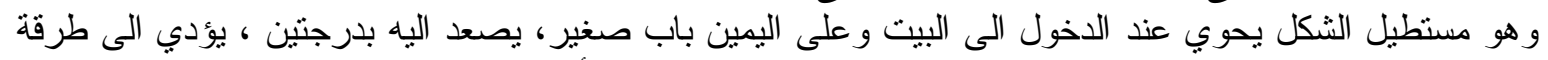

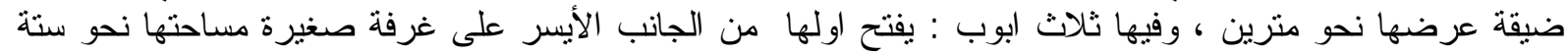

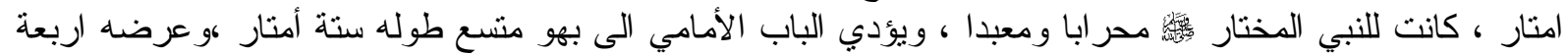

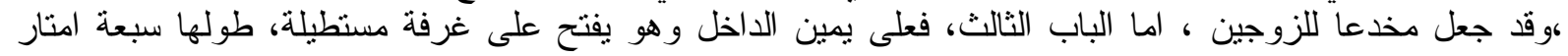

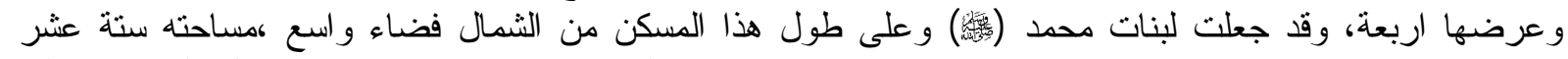

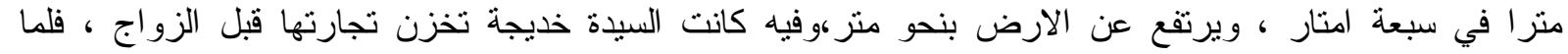

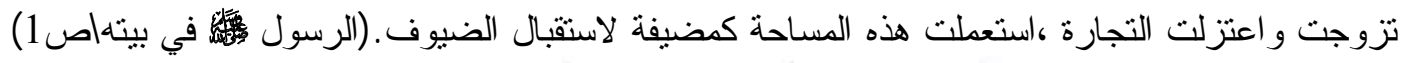

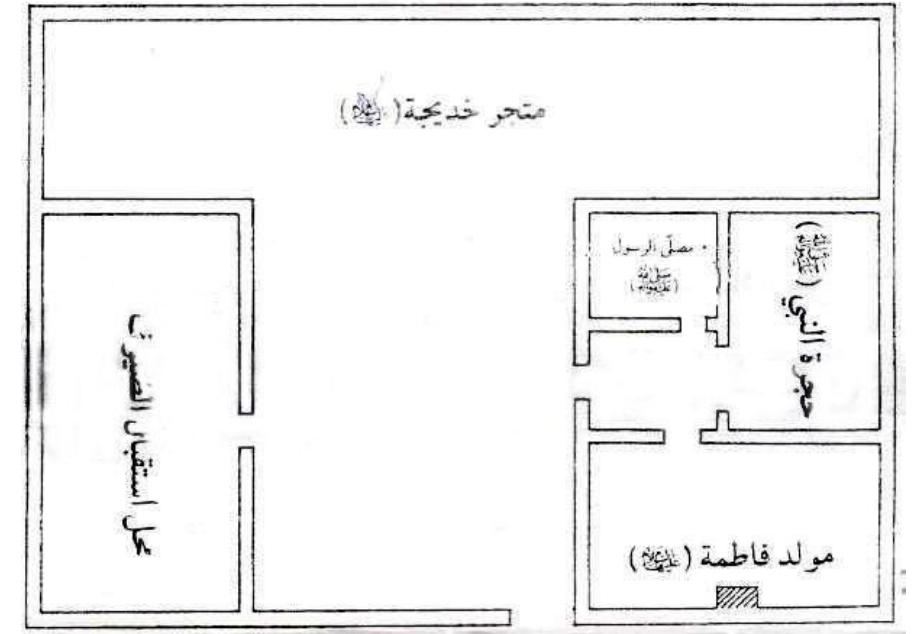

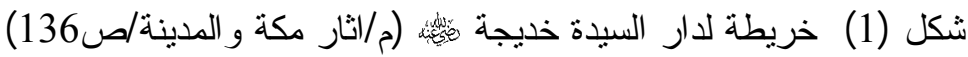

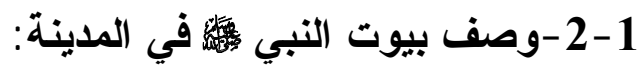

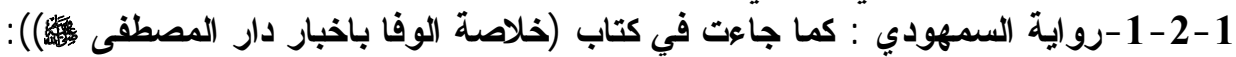

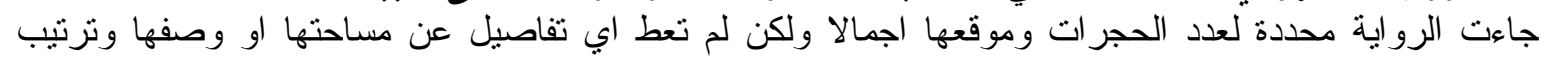

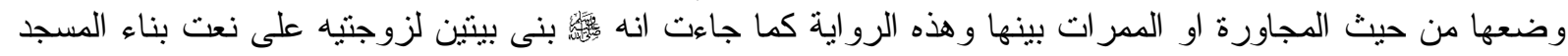

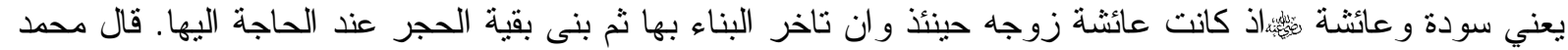
بن عمر كانت لحارثة بن النعمان منازل قرب المسجد وحوله وكلما احدث رسول الله بله

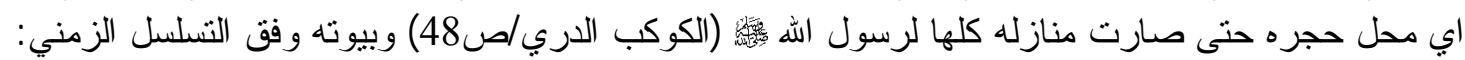
1

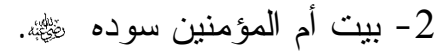

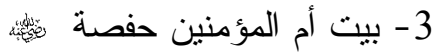

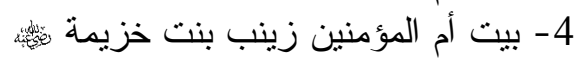




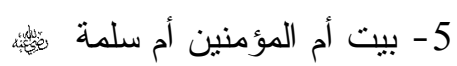

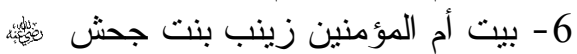

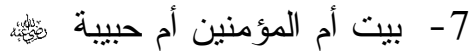

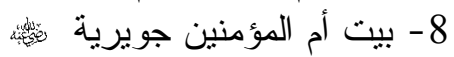

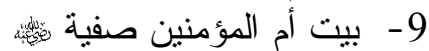

اما عن موقع البيوت: فقد اختلفت الروايات في دقة تحديدها ولكنها اكدت انها في الجهة الثرقية من المسجد يصل الـى الـى

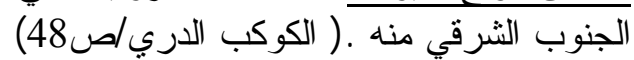

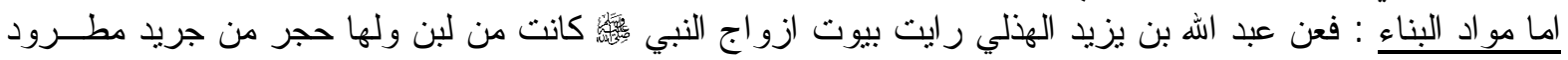

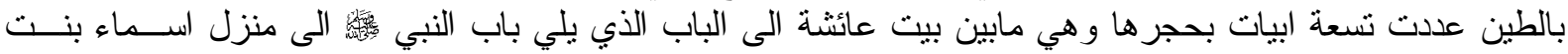

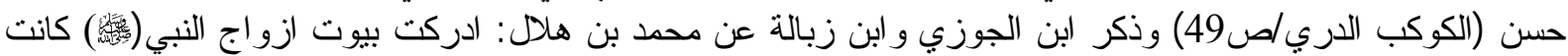

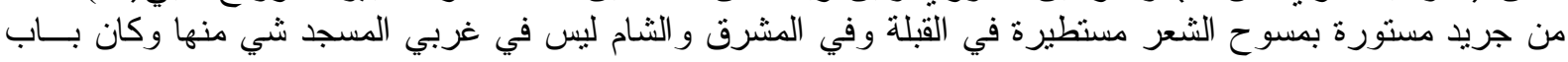

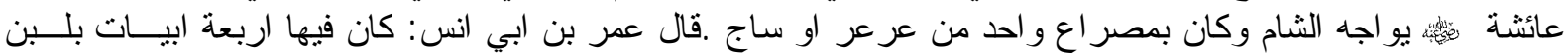

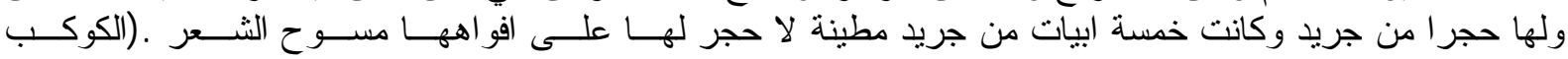

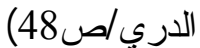

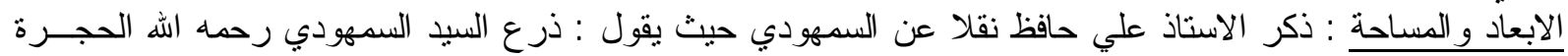

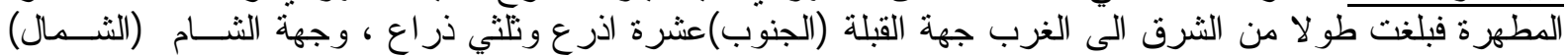

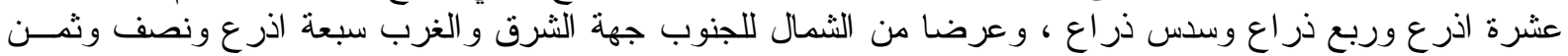

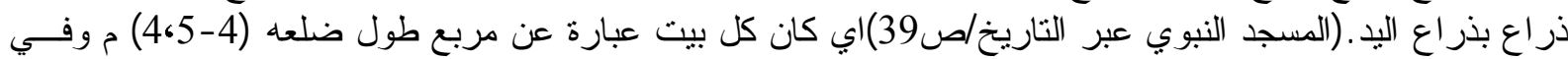

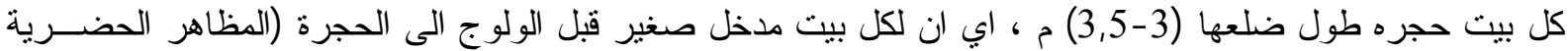

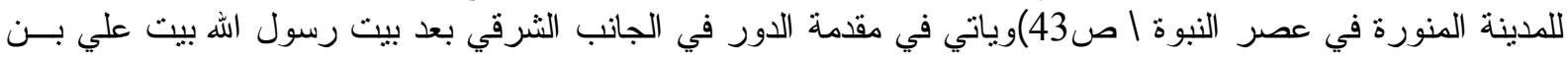

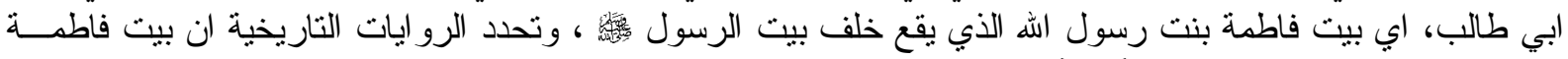

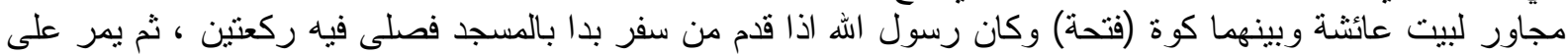

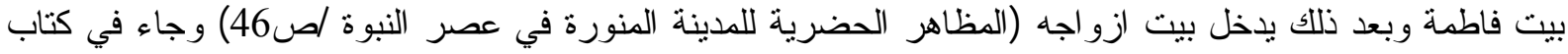

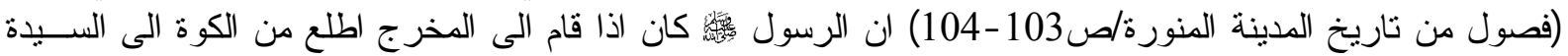

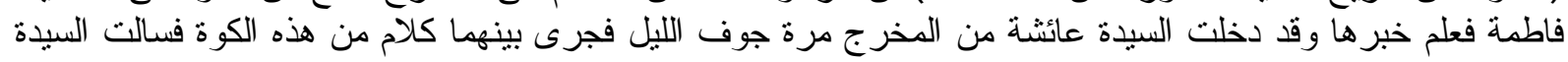

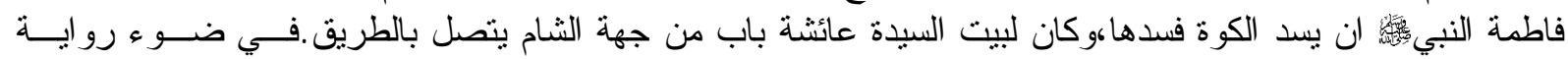

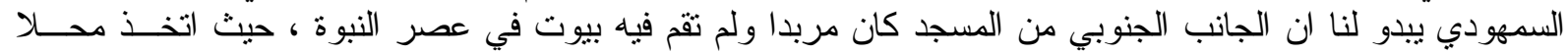

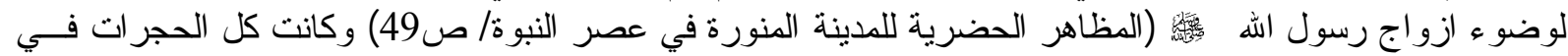
الجانب الشرقي خارج المسجد بابو اب شار عة الى المسجد.

: 2- 1

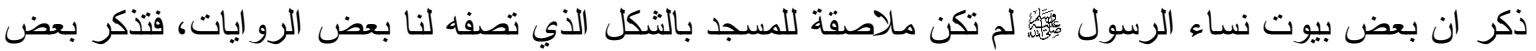

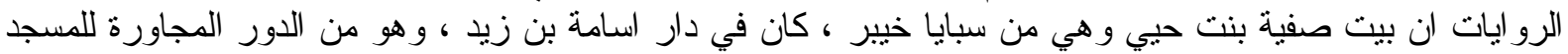

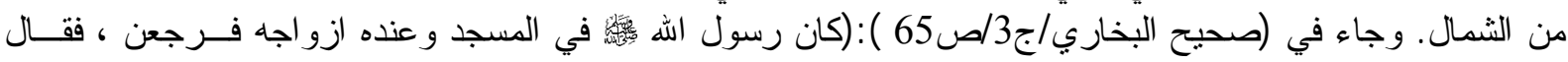

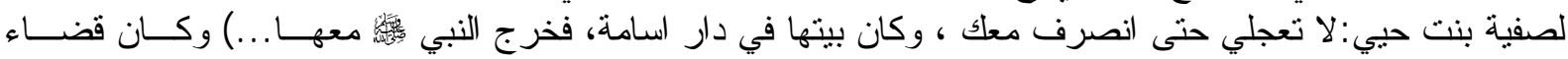

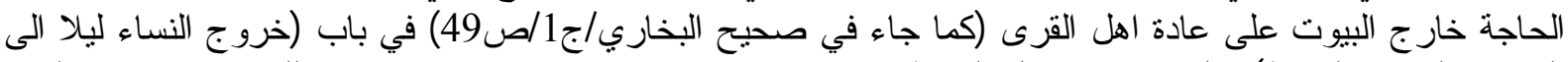

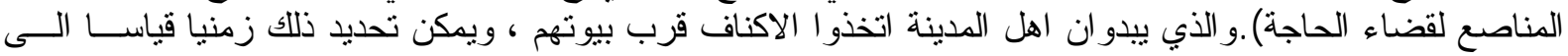

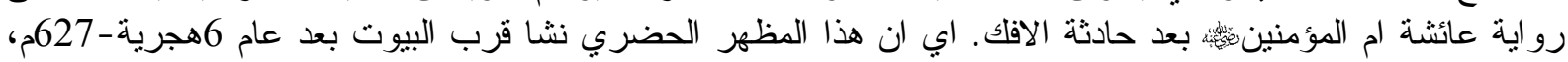

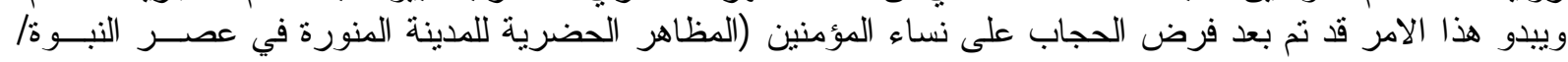

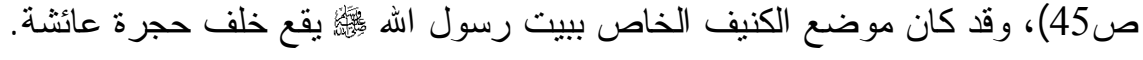

- 2- 1

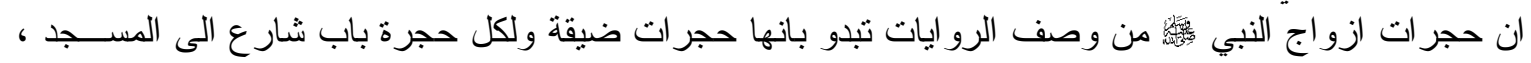

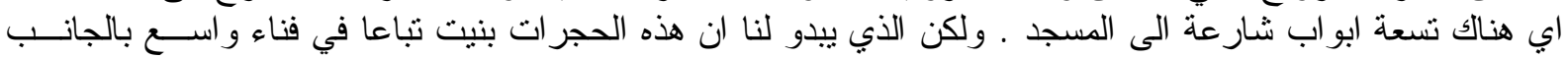

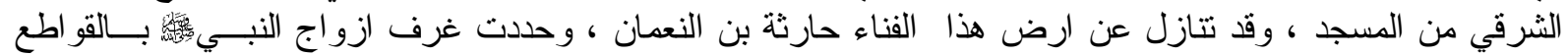

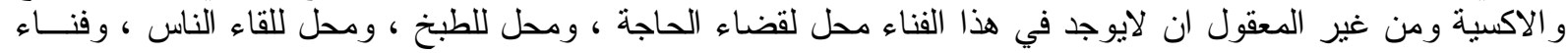

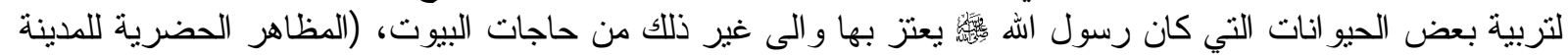

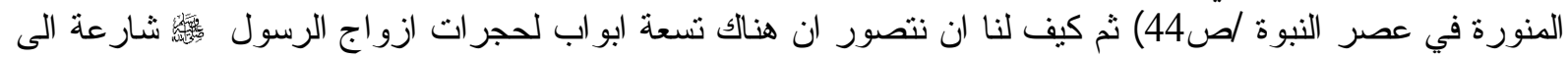




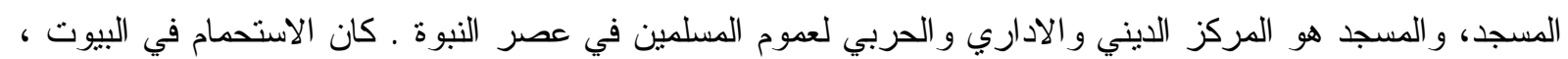

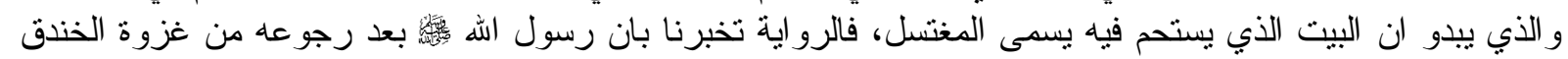

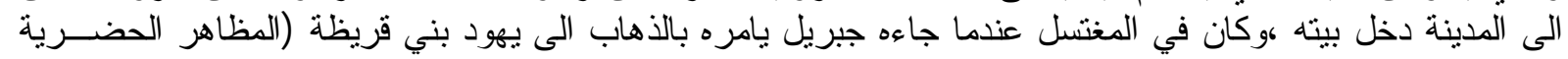

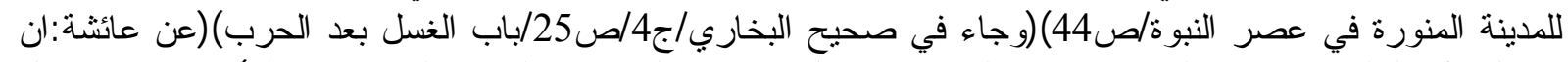

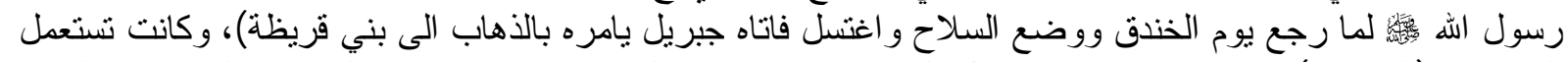

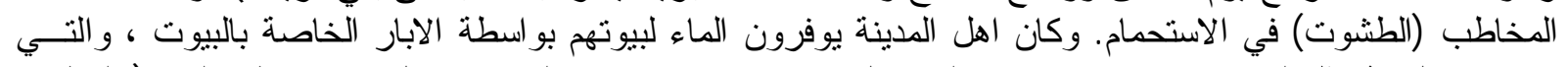

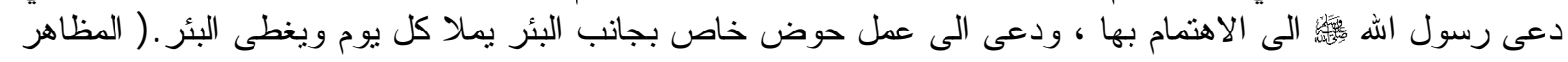

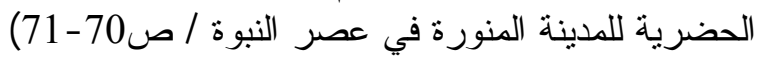

\section{1 - 1 - 2-وصف ابن سعد وابن النجار:}

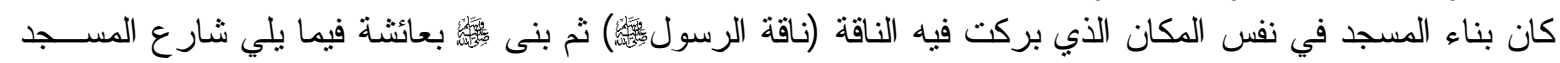

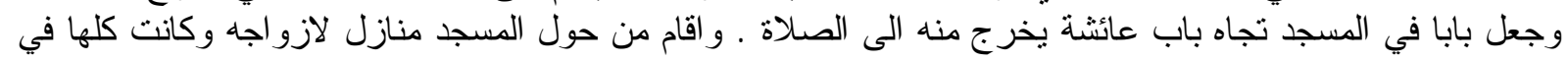

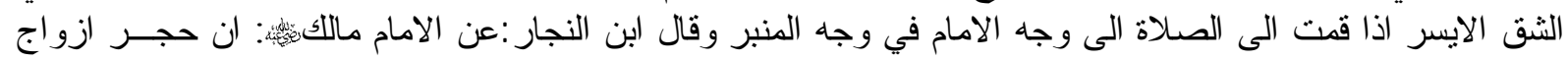

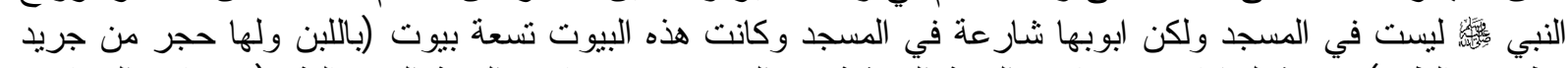

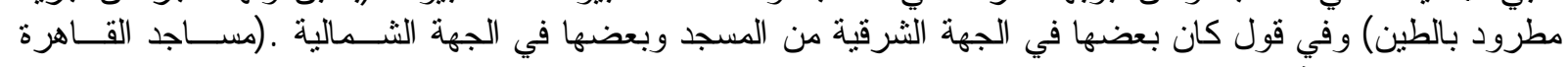

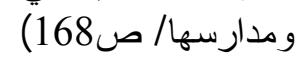

\section{1 - 1 - 1 -وصف (بن رستة:}

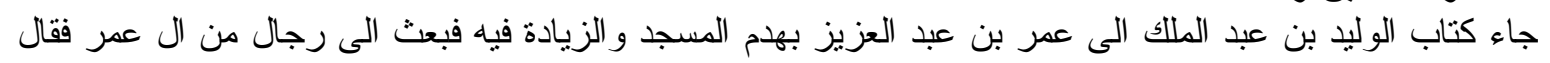

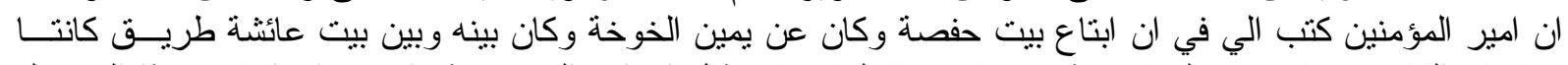

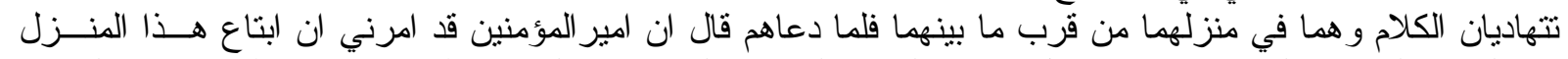

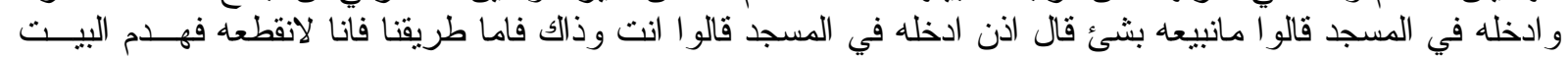

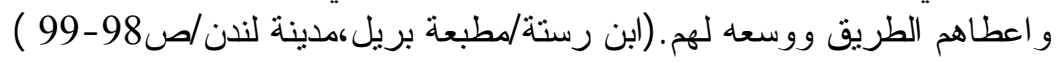

:

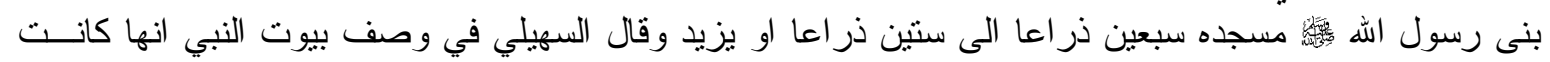

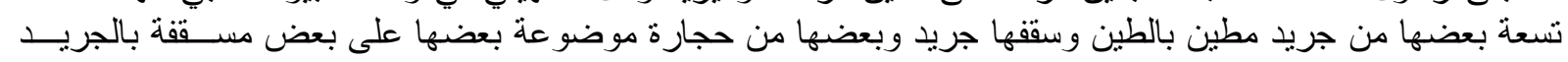

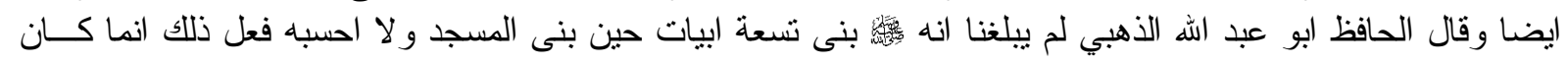

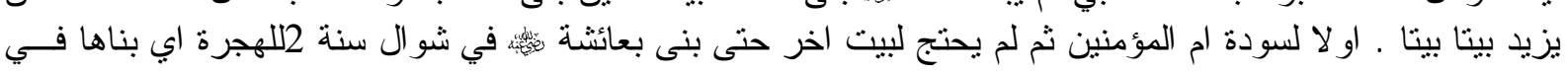

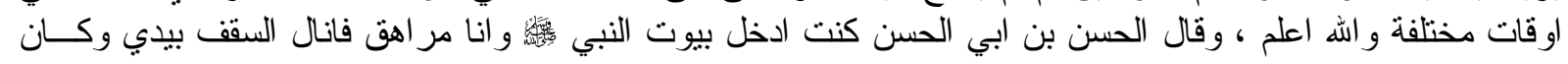

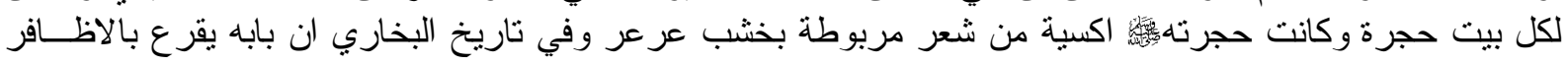

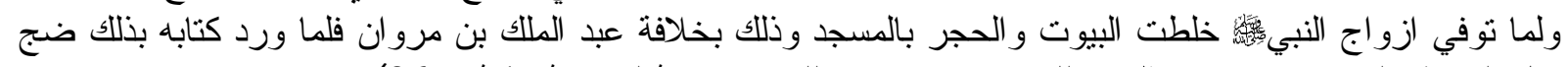

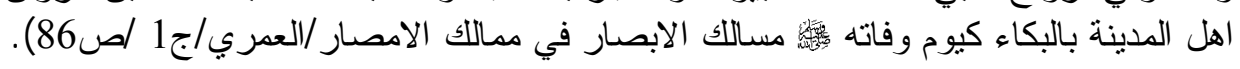

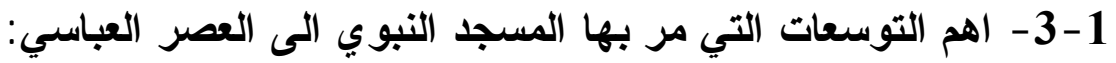

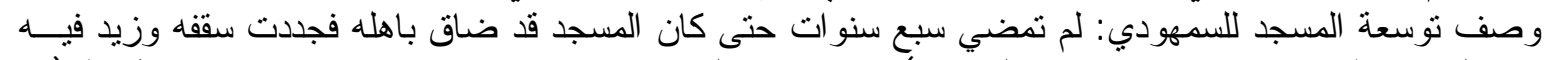

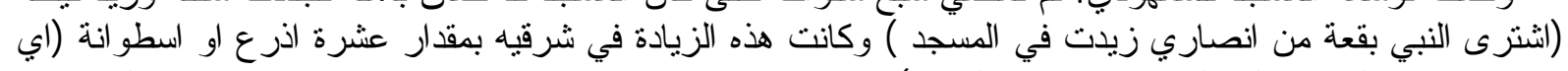

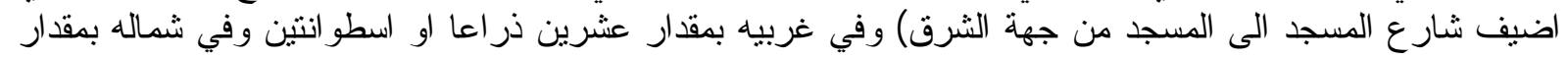

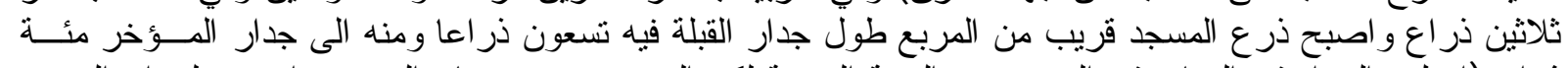

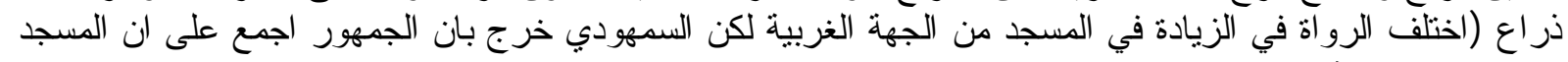

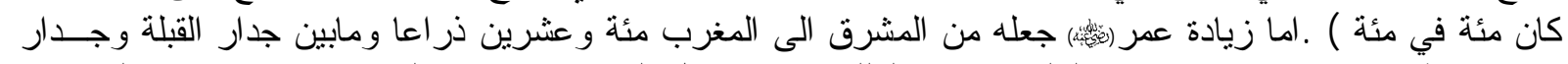

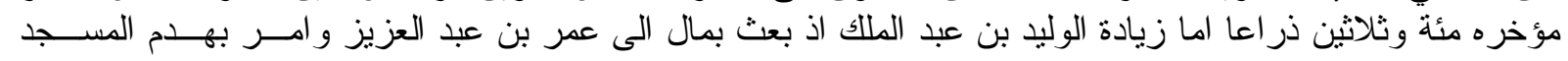

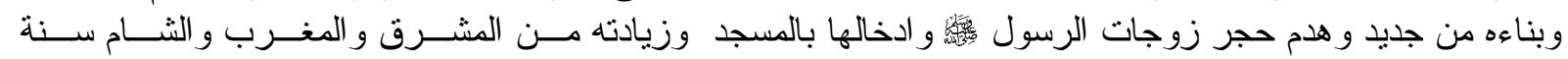

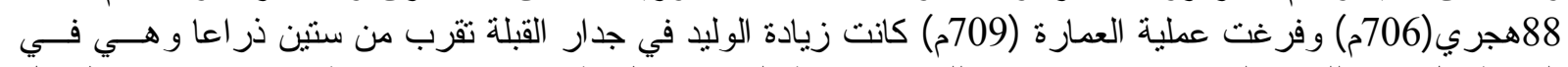

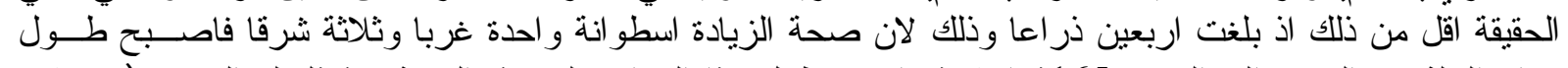

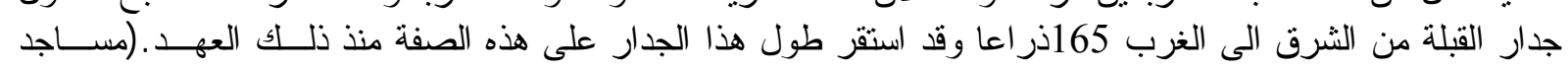

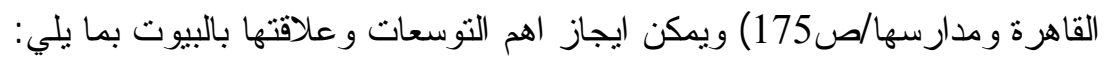




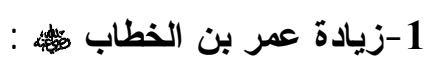

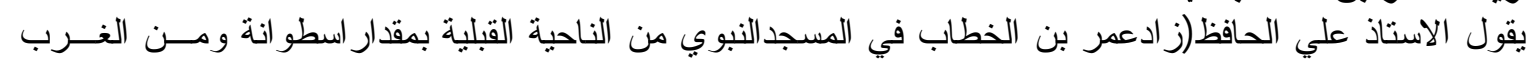

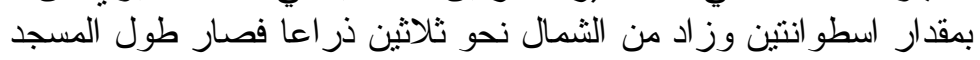

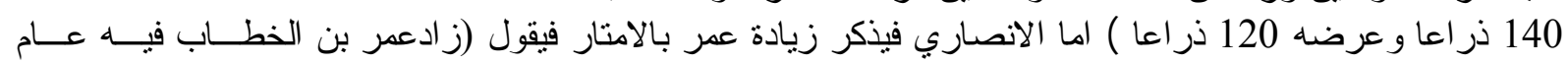

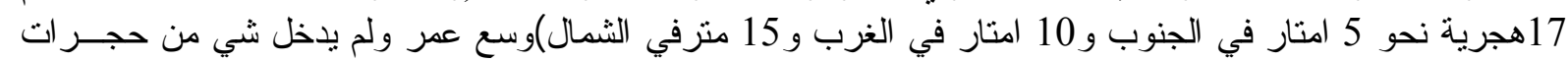

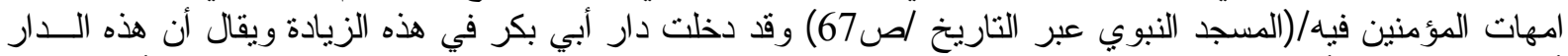

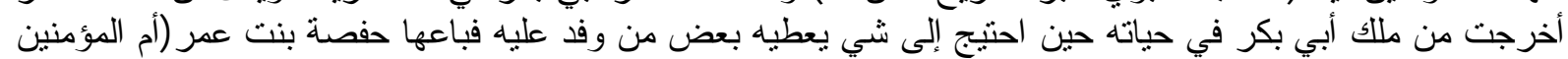

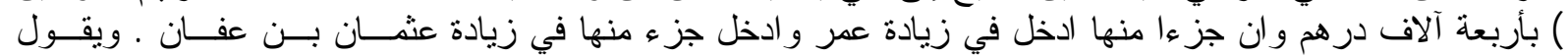

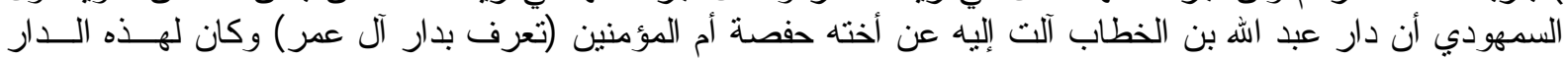

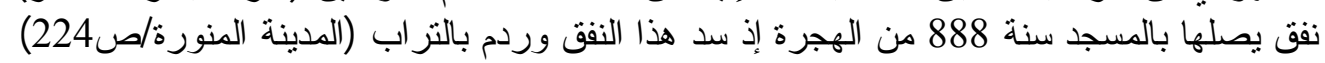

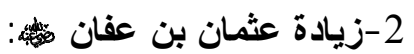

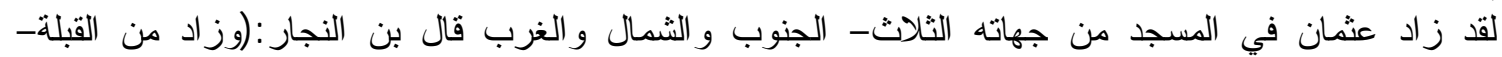

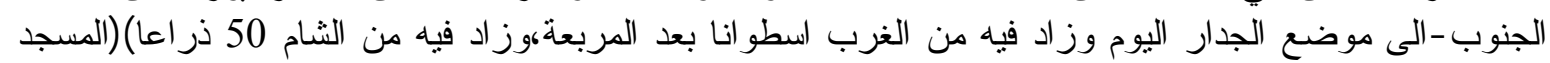

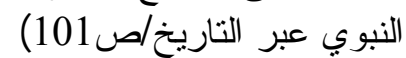

ثم يقول الاستاذ علي الحافظ :(زاد فيه عثمان بن عفان من جهة القبلة قدر اسطوانة ومن الغرب قدر اسطوانة اليضا

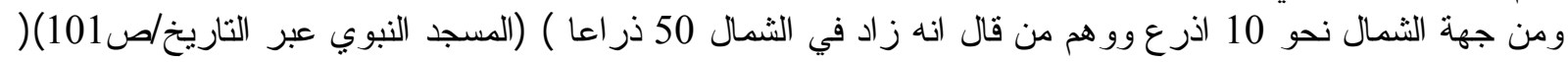

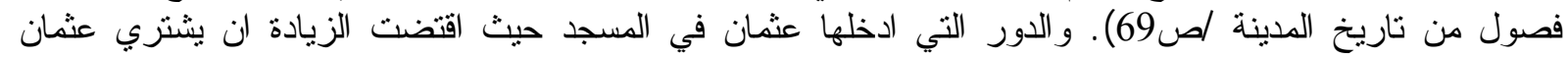

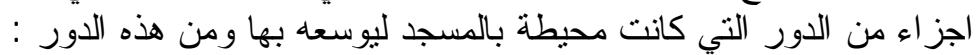

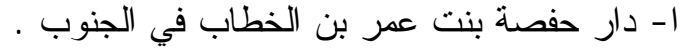

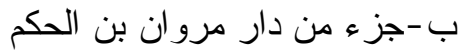
ج -جزء دن دار جن دار مرفر بن ابي طالب.

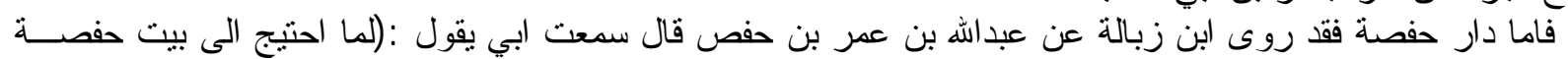

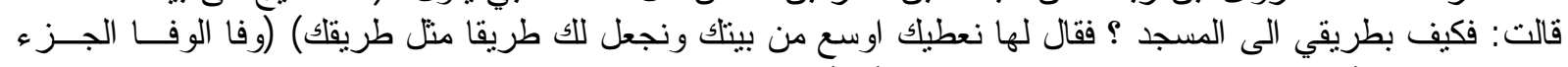

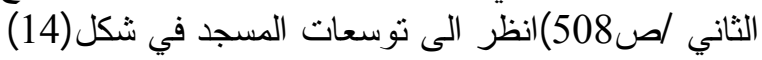

3 - زيادة الوليد بن عبد الملك:

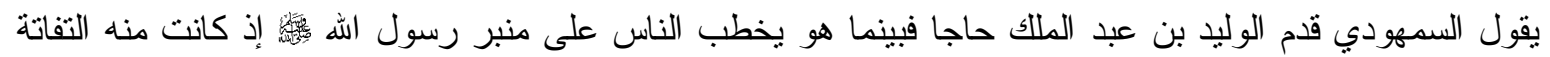

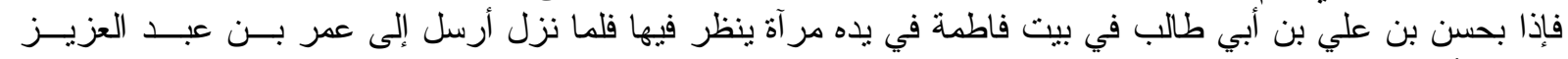

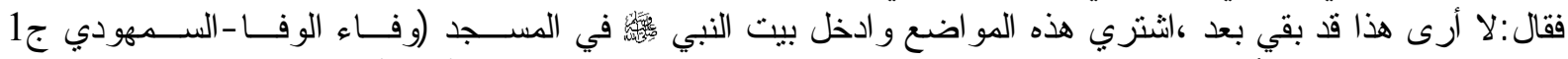

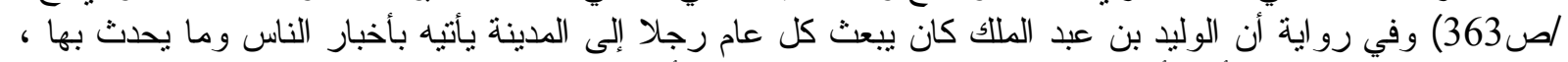

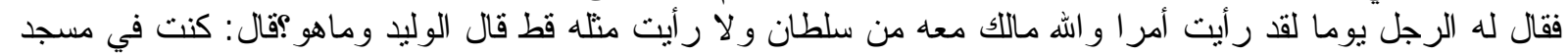

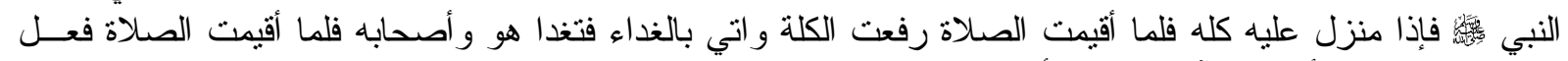

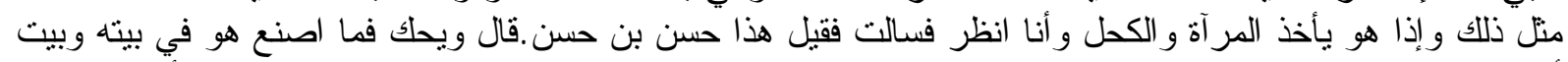

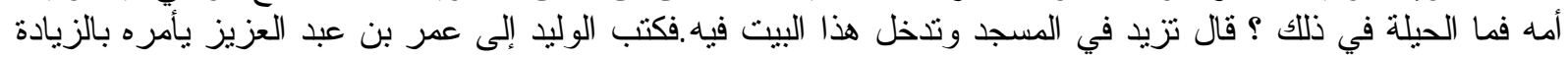

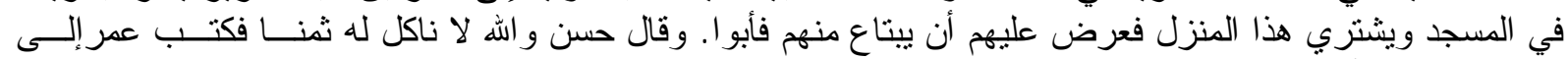

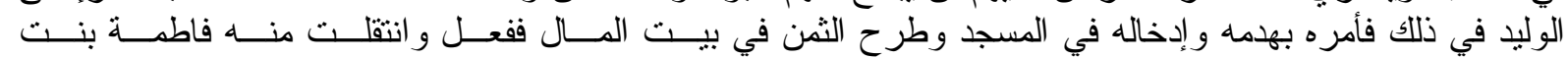

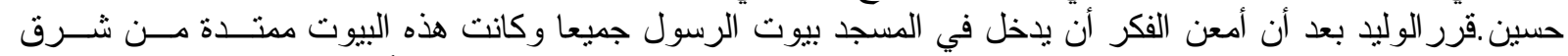

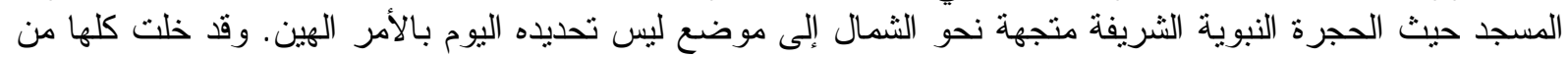

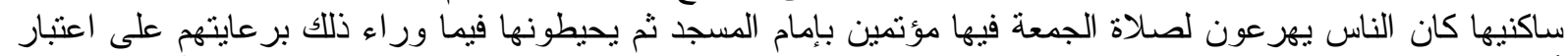

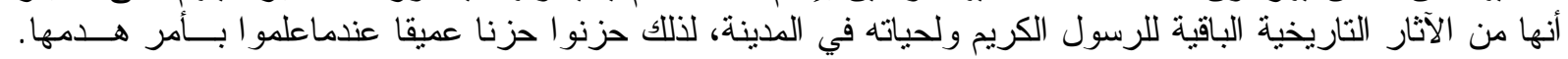

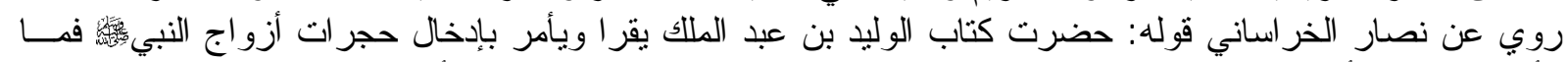

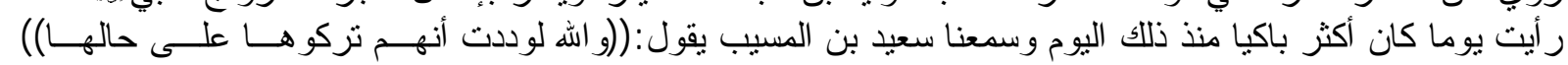

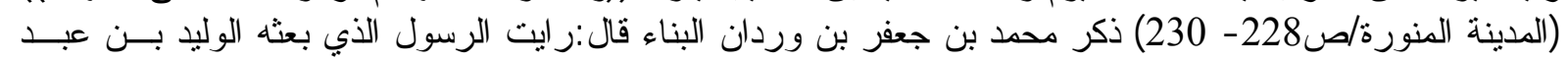

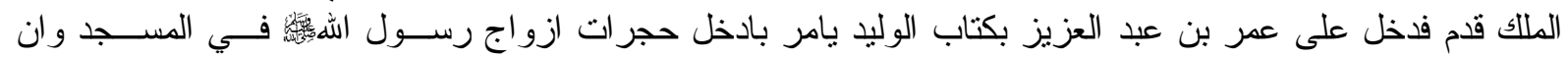

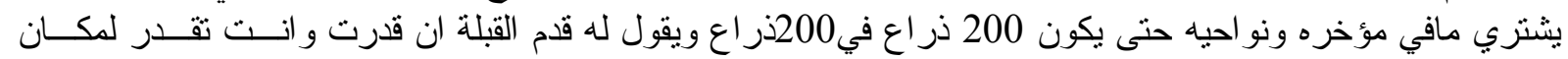

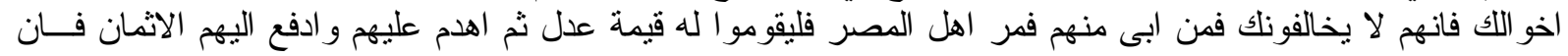

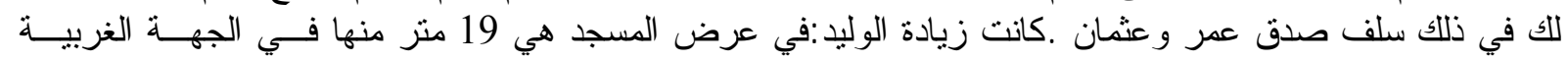




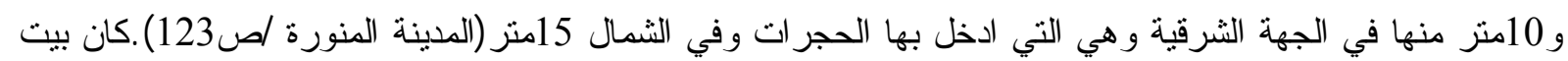

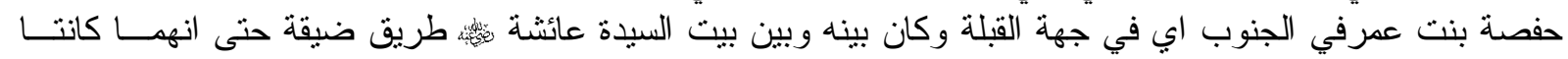

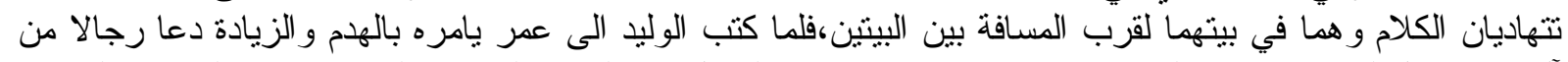

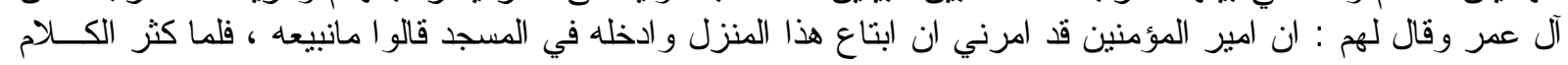

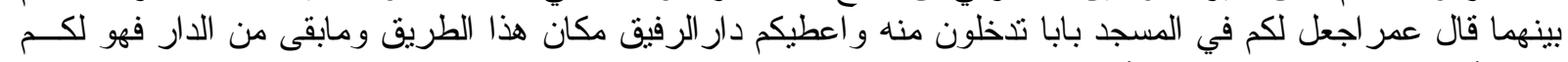

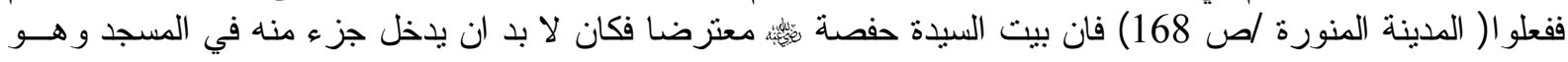

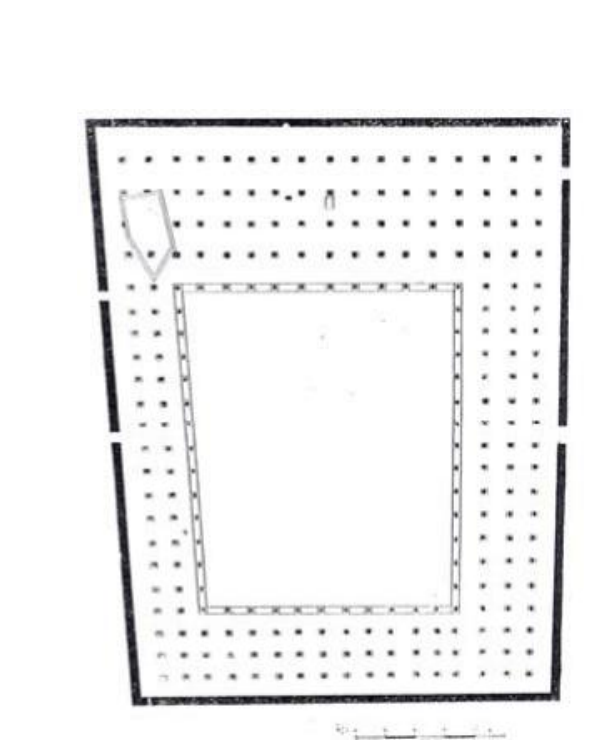

شكل(4)التوسعة في عهد الوليد(مساجد القاهرة ومدارسها)

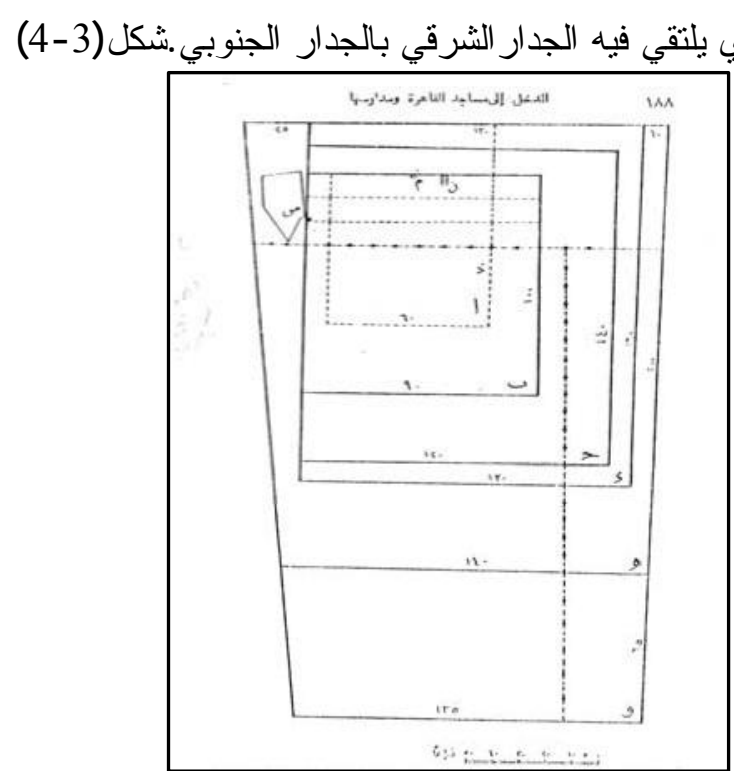

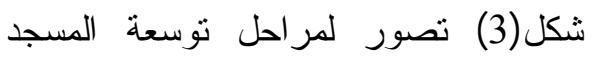
النبوي منذ إنشائه الى عهد الوليد

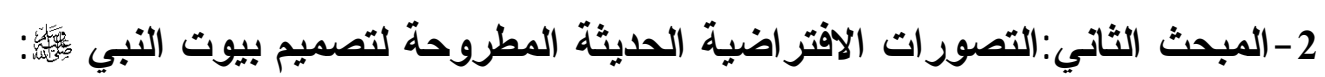

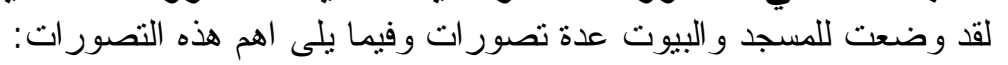

2-1- 2

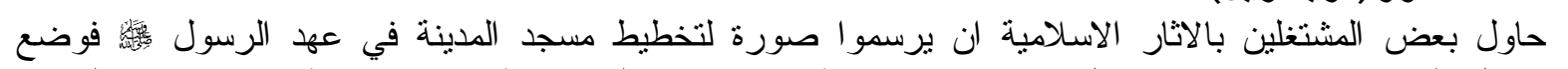

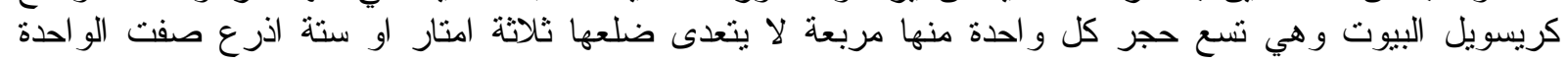

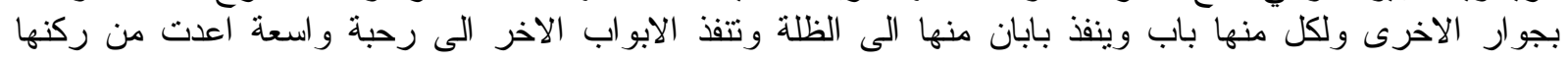

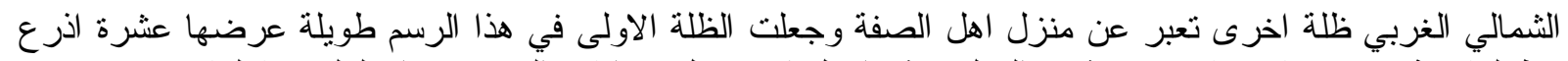

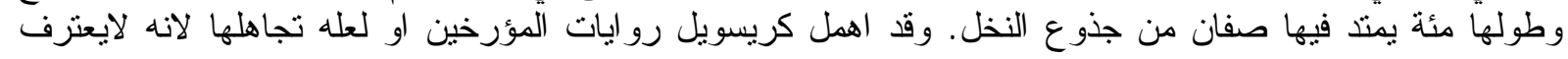

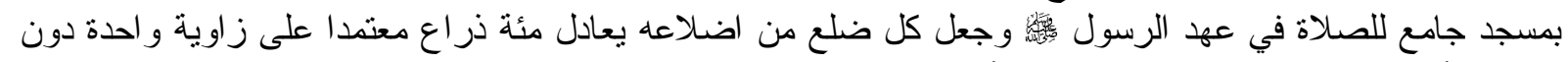
تمحيص(مساجد القاهرة ومدارسها/ص في لرد 182)

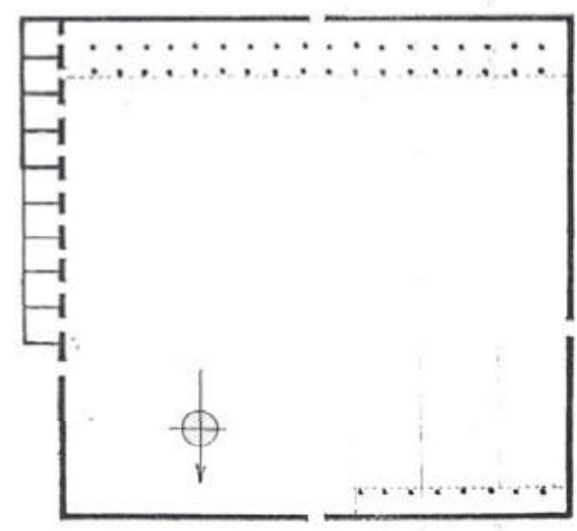

شكل(5) صورة من تخيل كريسول للرسم التخطيطي للمسجد

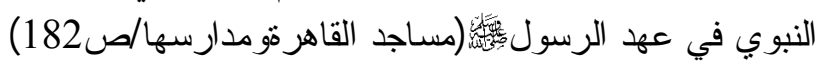


2-2 -وصف وتصور محمود عكوش:

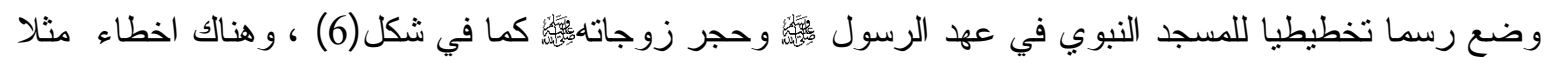

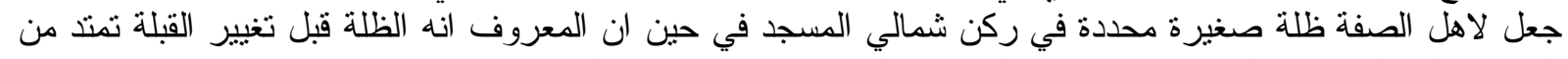

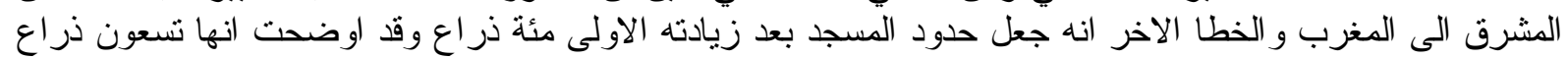

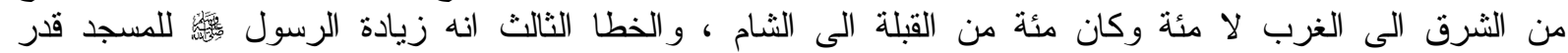

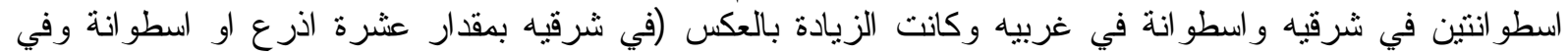

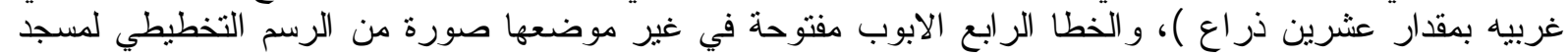

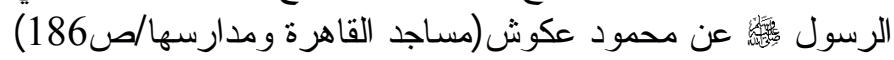

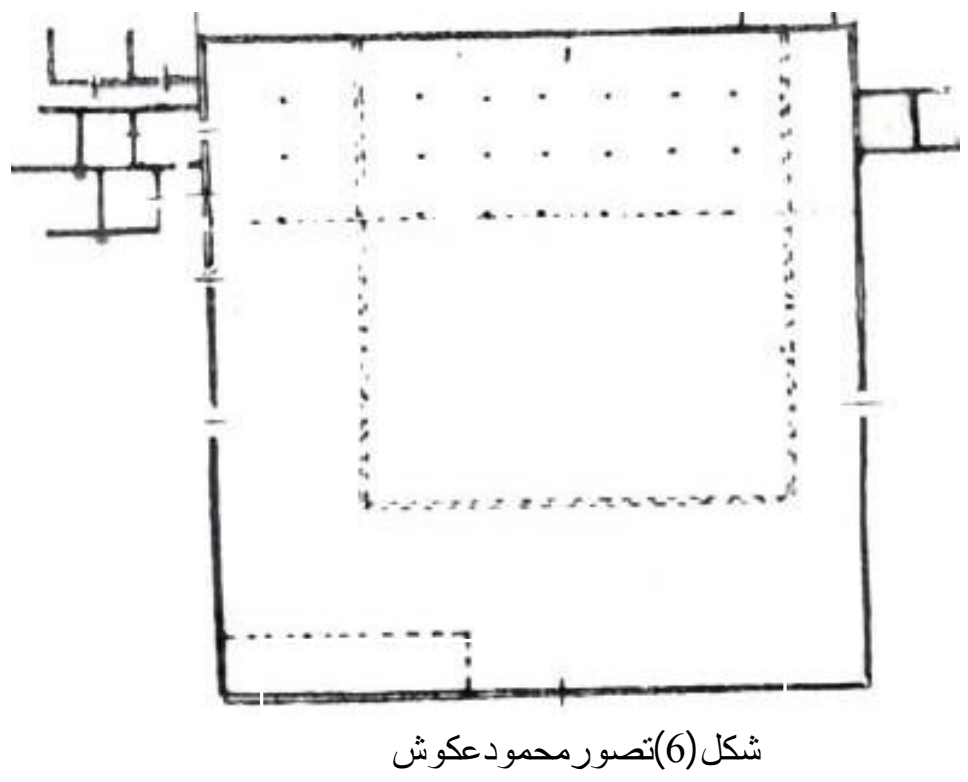

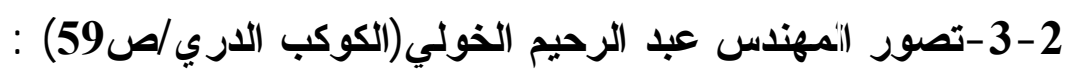

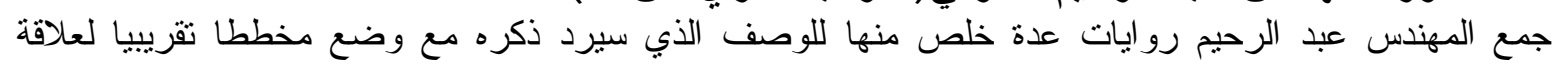

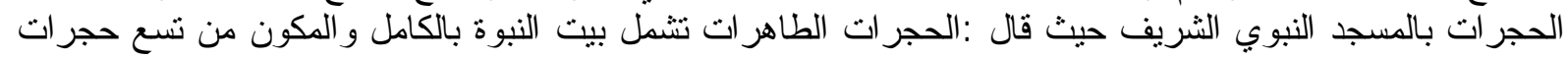

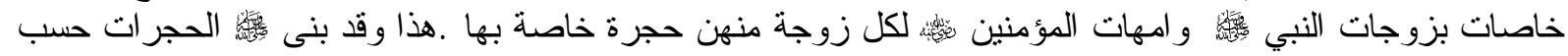

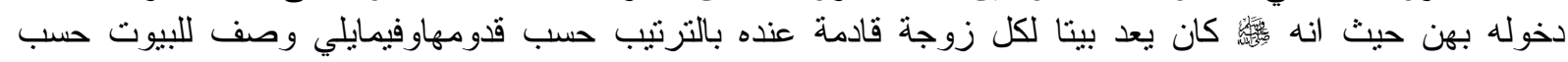
تصور المهندس من جوانه انب انه عدة منها:

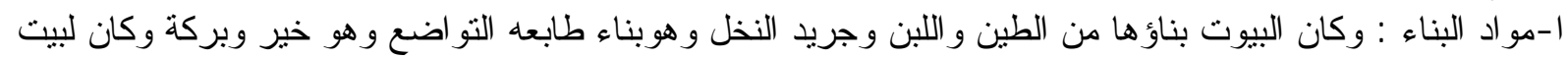

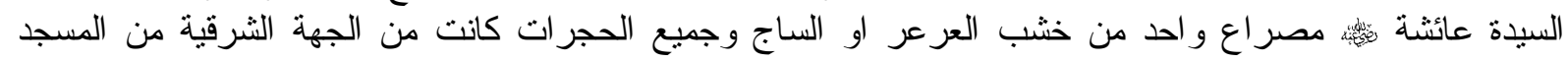

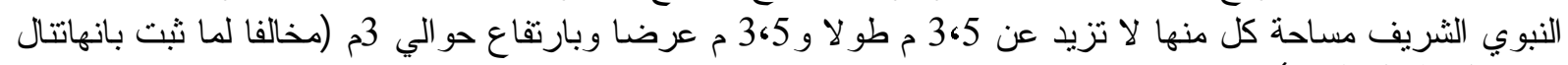
بيد رجل طويل القامة) ب بيدوصف الفتحات : وقد كان لكل بيت بابان احدهما في المسجد و الاخر مشرعا في الطرقات عليه مسوح من جلد اما

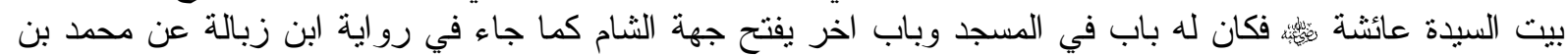

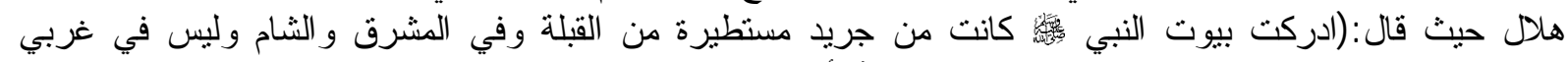

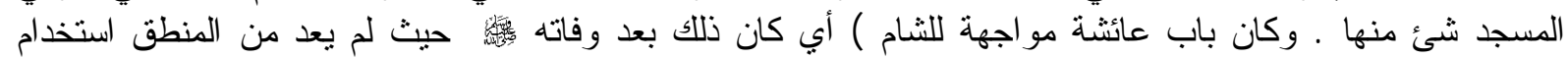

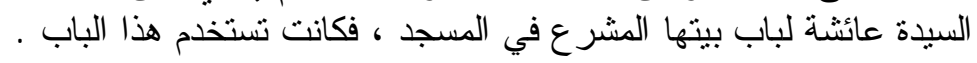

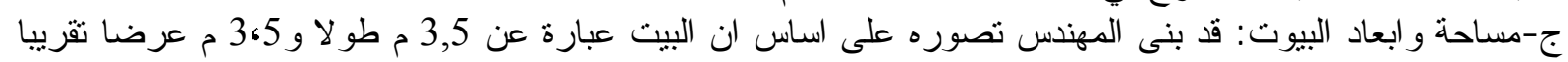

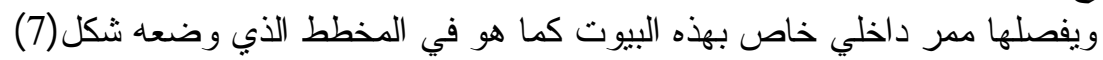

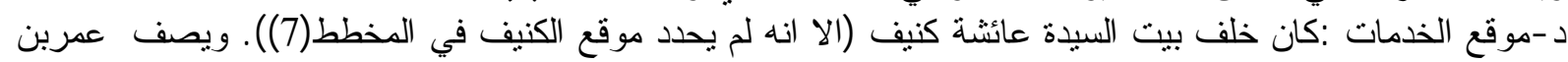

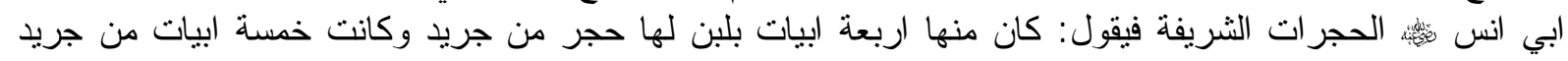

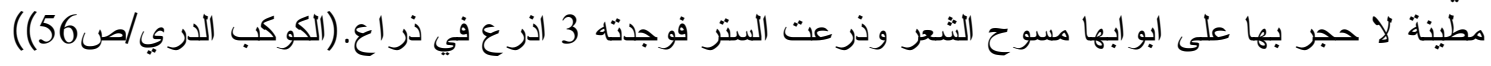




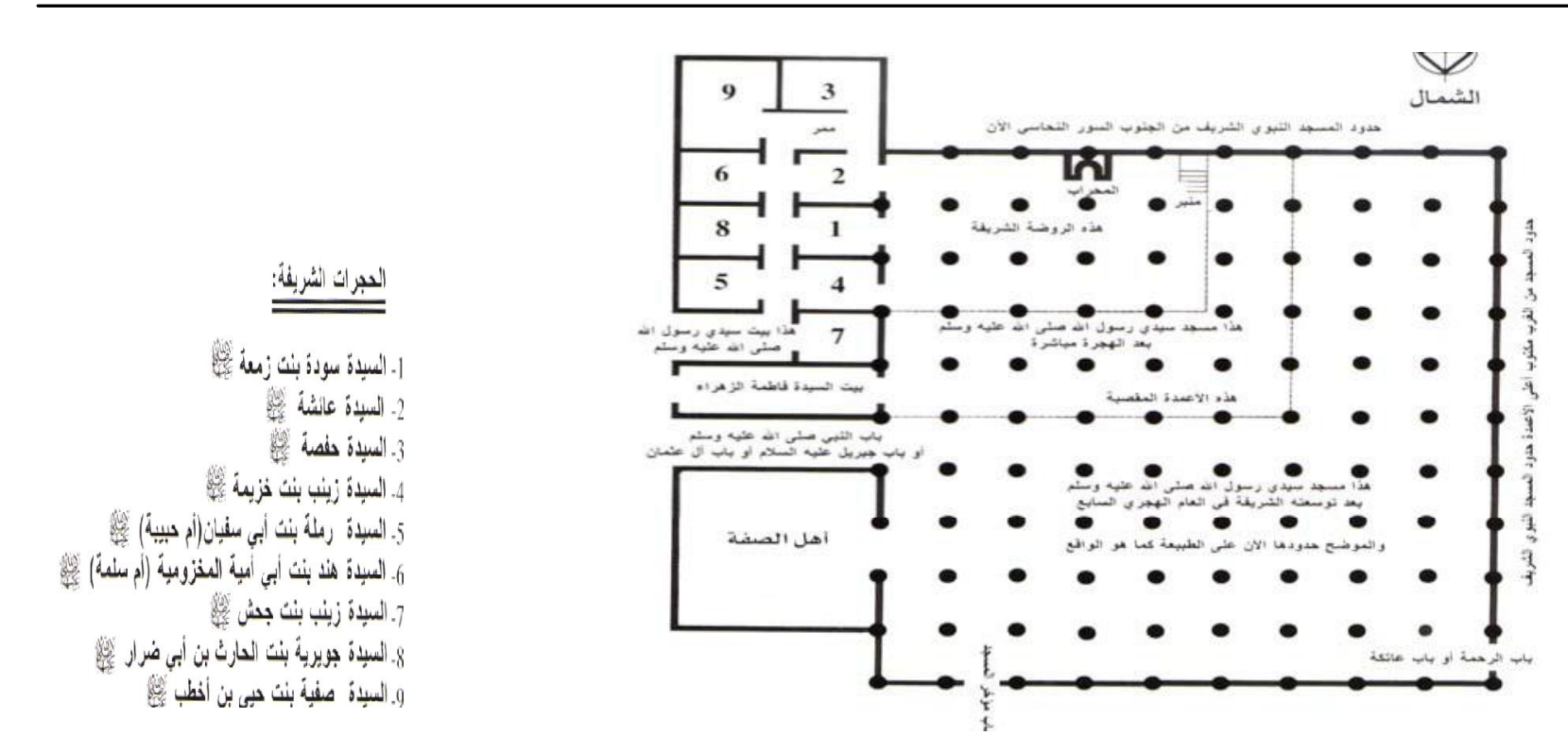

$$
\text { شكل(7)مخطط حسب تصور المهندس عبد الرحيم الخولي لعدد ومواقع البيوت /(الكوكب الدري/ص4) }
$$

\section{2- 2 - -تصور (لاكتور المهندس (حاتم عمرطه):}

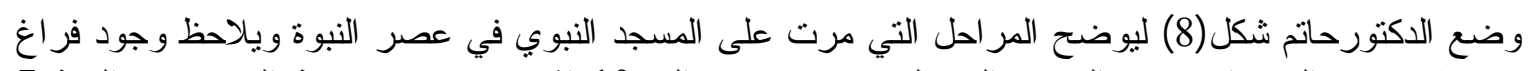

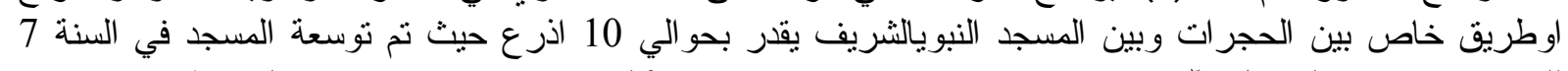

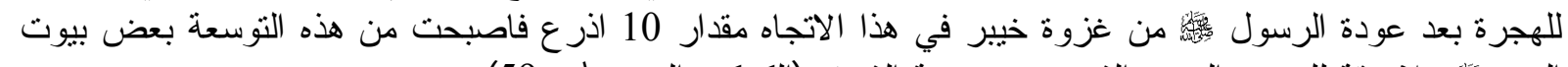

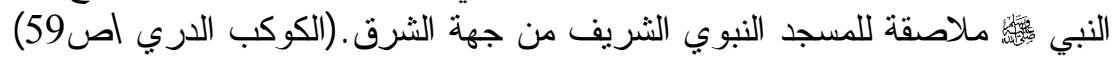
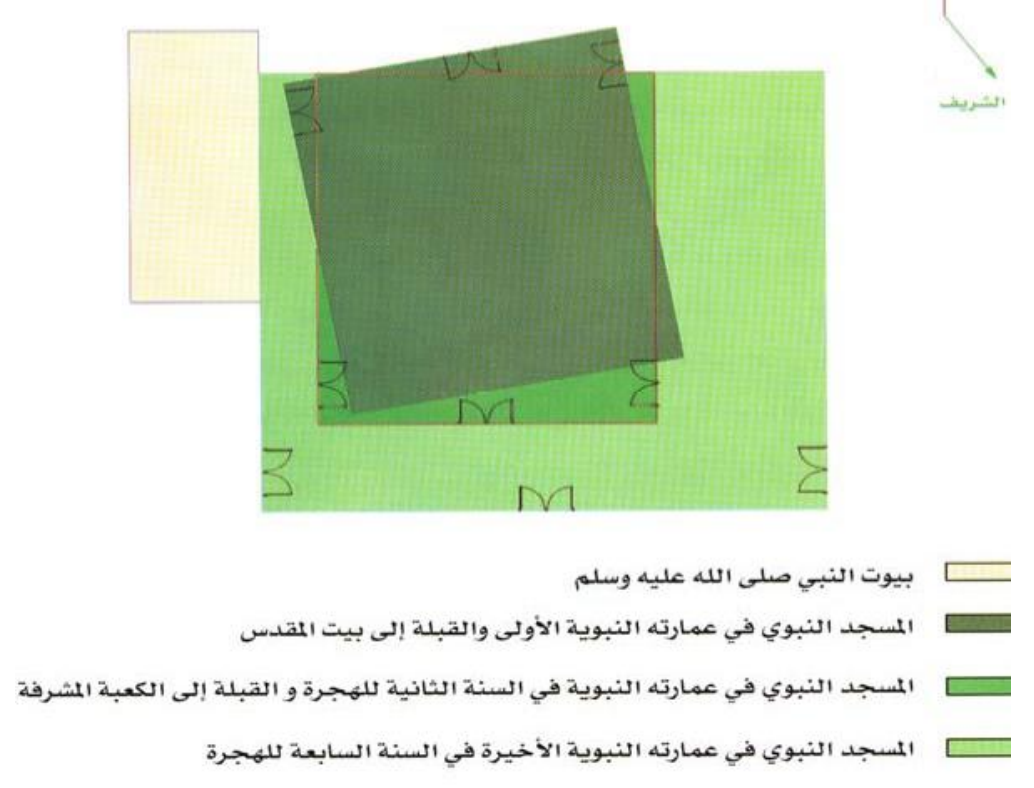

شكل(8) (الكوكب الدري/ص60) رسم يوضح المراحل الثلاث التي مرت على المسجد النبوي

الثريف في العمارة النبوية ويلاحظ ان هناك ممر او فر اغ يفصل المسجد عن البيوت اضيف للمسجد

$$
\text { في سنة 7هـ بعد غزوة خيبر }
$$




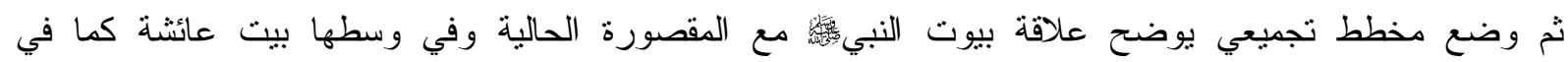
شكل(9)(الكوكب الدري/ص60)وكذلك وضع تصور تقريبي ناتج من در اسة علاقات البيوت بالمسجد شثكل

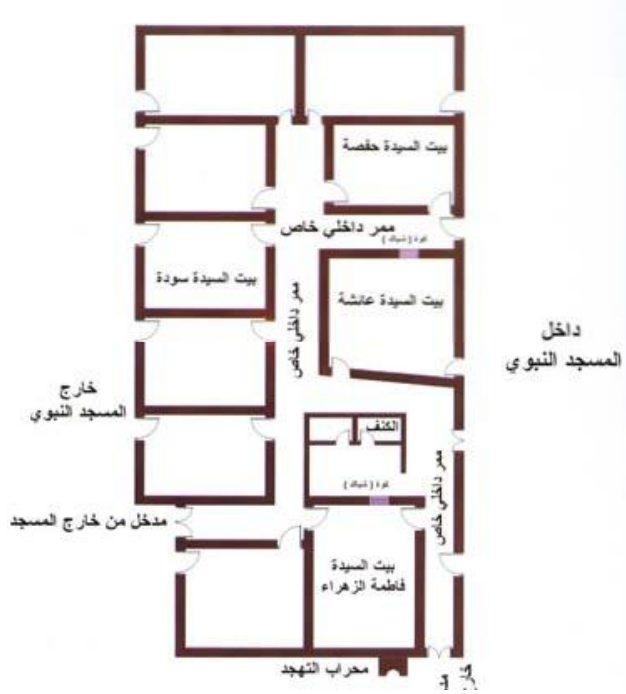

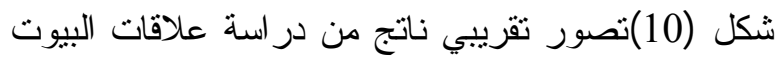

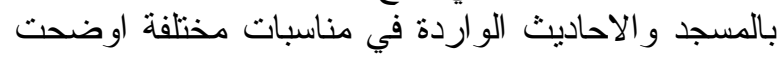

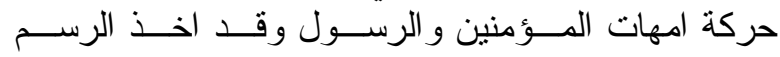

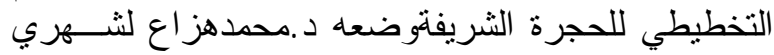

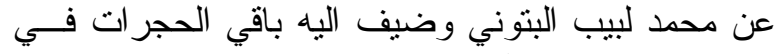

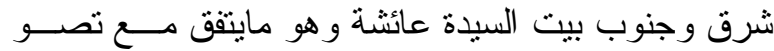

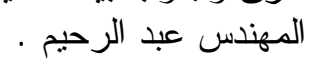

\section{2-2 -تصور فضيلة الاستاذ منصور عبد الحكيم محمد:}

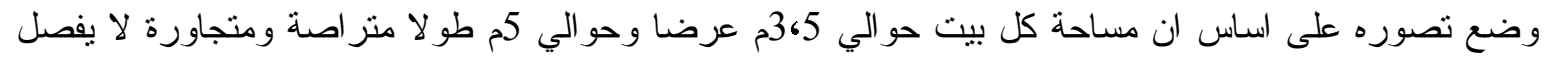

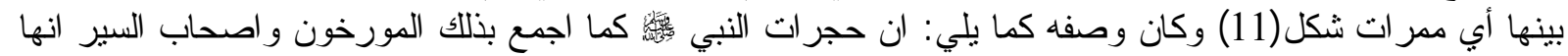

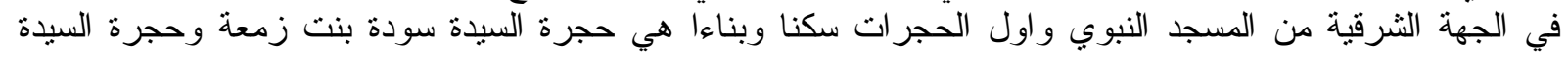

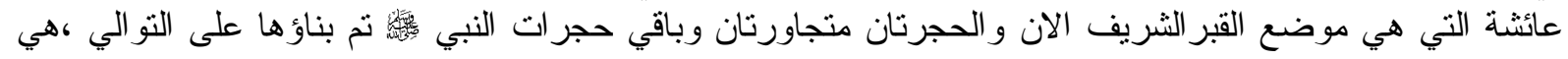

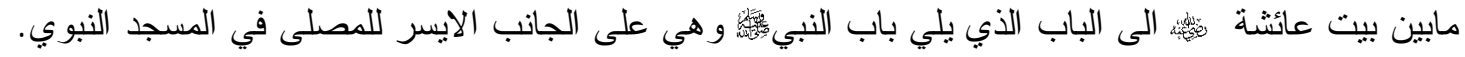

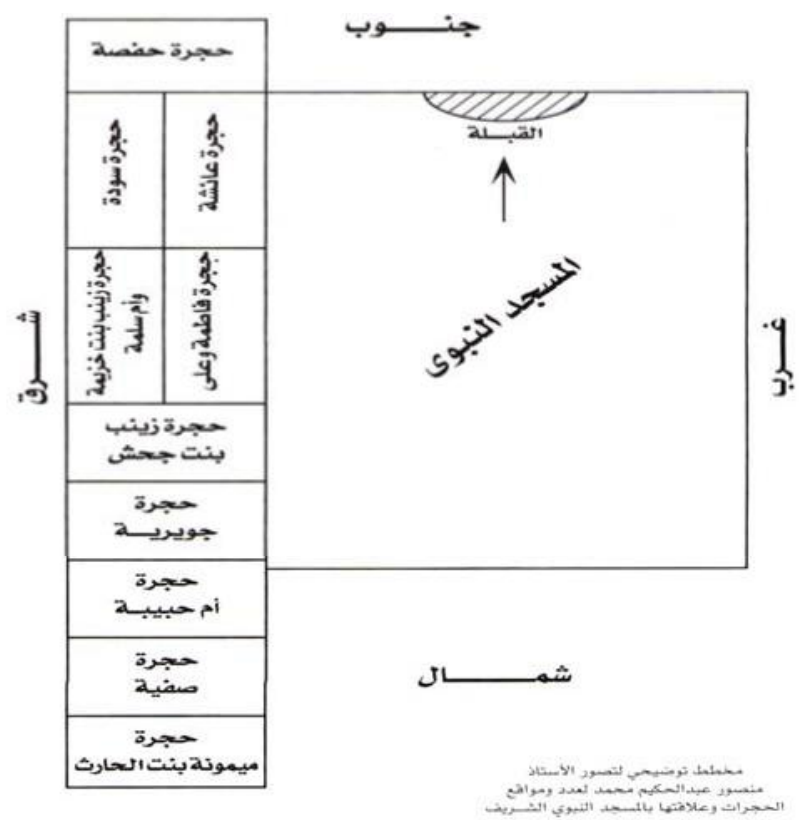




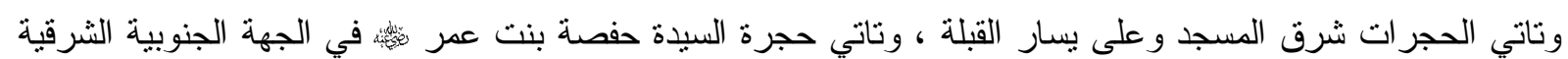

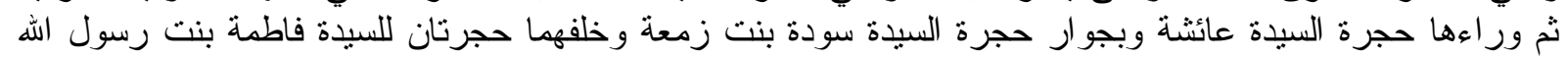

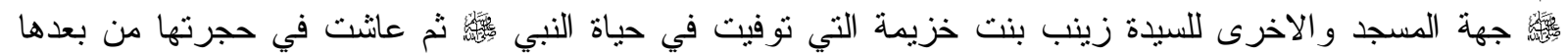

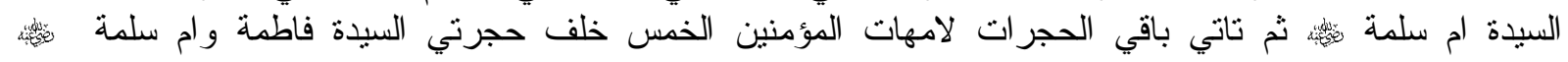

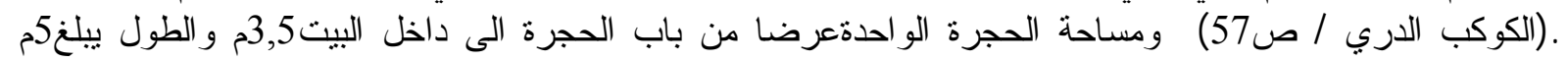

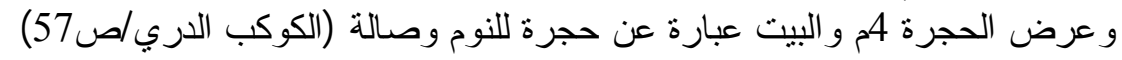
2 -6 -وصف اللواء رفعت باشا في كتاب/مراة الحرمين الشريفين(الرحلات الحجازية)/نقلاعن (الكوكب الاري/ص25):

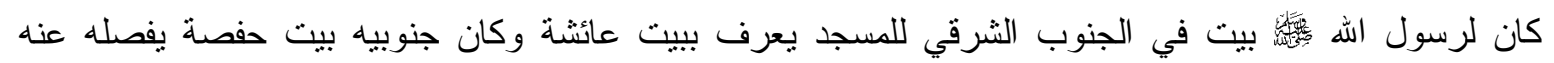

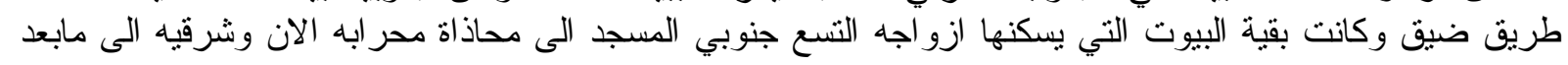

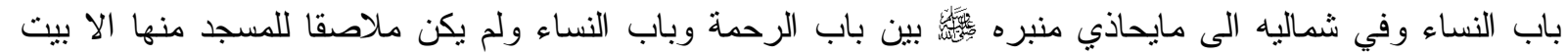

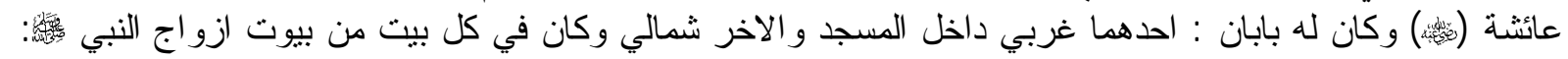

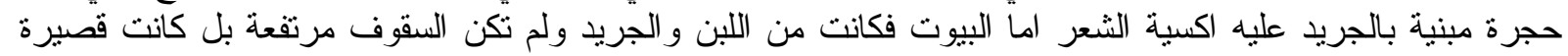
تنال باليد.

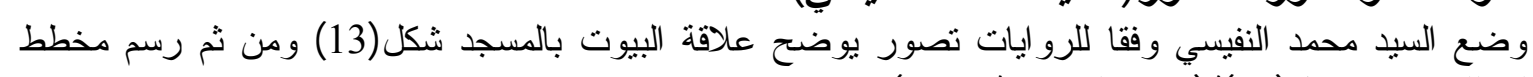

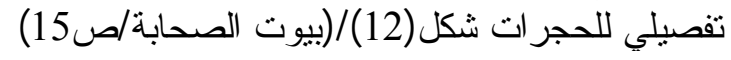

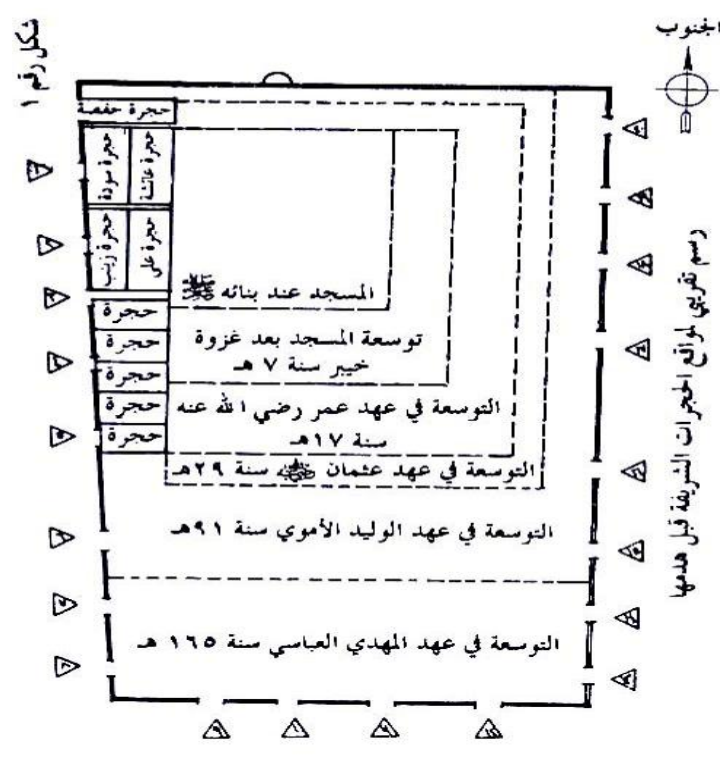

شكل(13)مخطط يوضح علاقةالبيوت مع المسجد

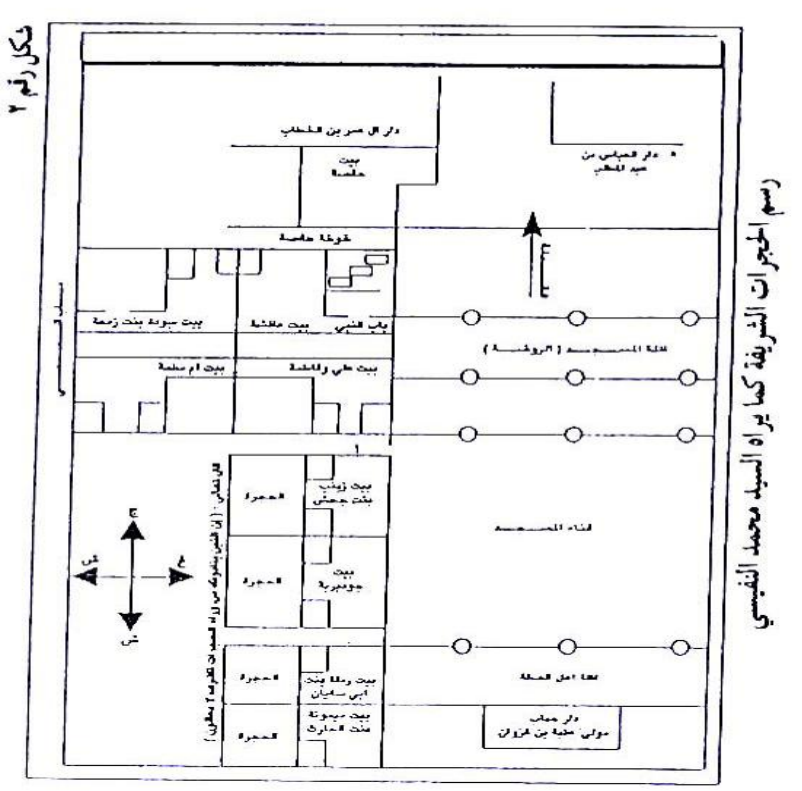

شكل(12) مخطط بوضح تفاصبل الحجرات

3 -المبحث الثالث: استنباط مكونات البيوت وخصائصها ثم مناقشة التصورات ووضع تصور افتر اضي للبيوت

3-1-1-1 - 3 - 1 -

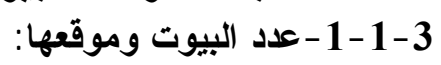

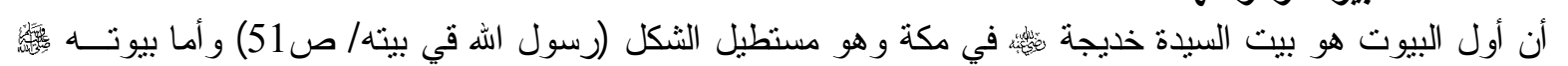

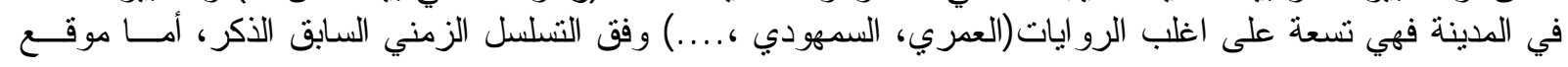




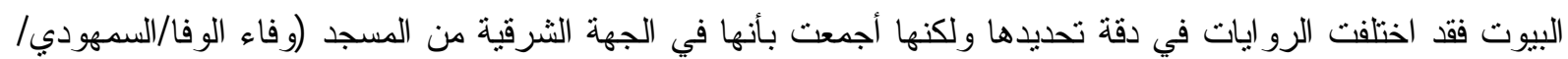

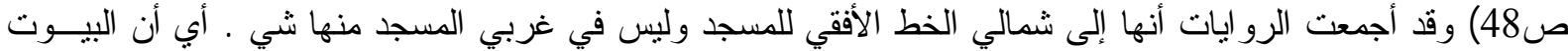

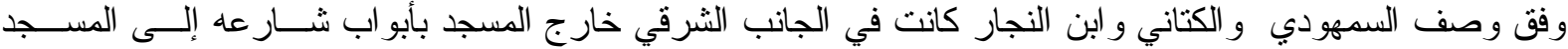

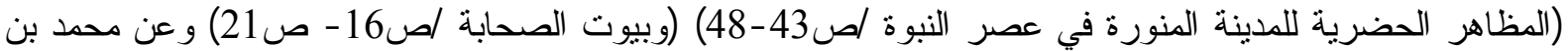

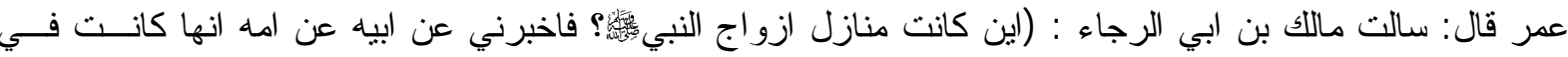

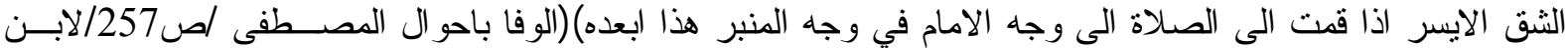

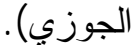
ويأتي في مقدمة الدور بيت رسول اله بئو (بيت عائشة)وقد بين صاحب الكوكب الدري ان هناك فر اغ بين المسجد و البيوت يقدر بحو الي 10 اذرع حيث نم توسعة المسجد بعد عودة الرسول من غزوة خيبر سنة(7)هجرية باتجاهيا

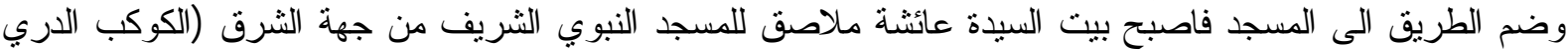

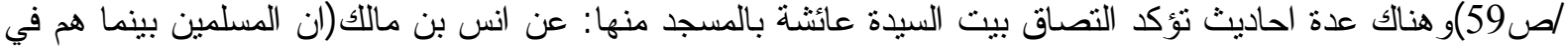

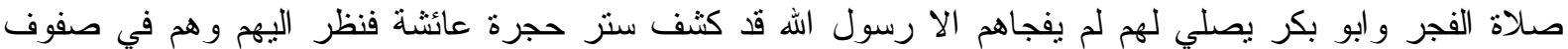

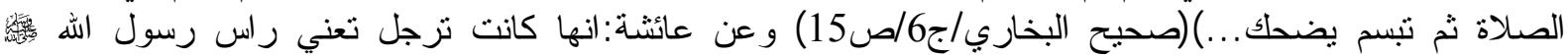

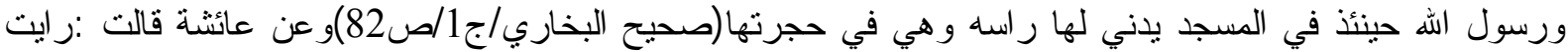

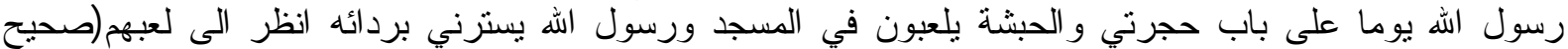

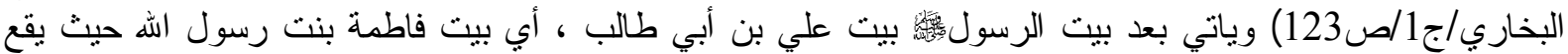

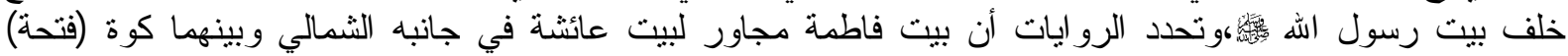

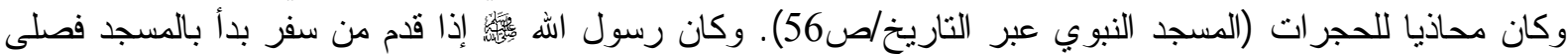

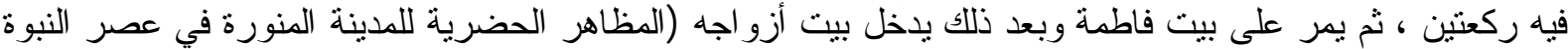

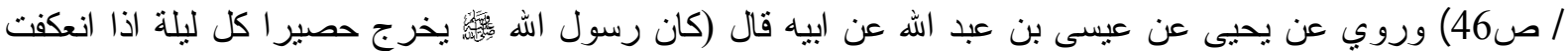

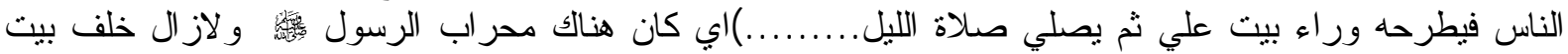

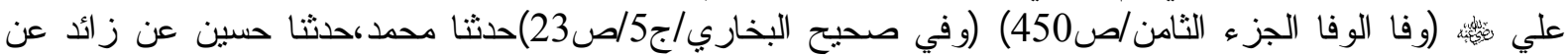

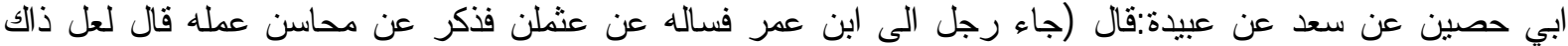

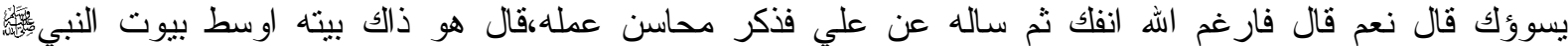

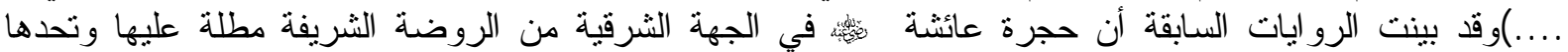

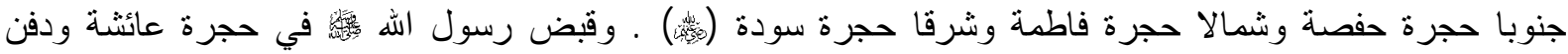

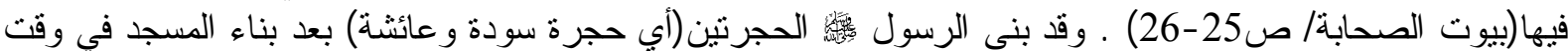

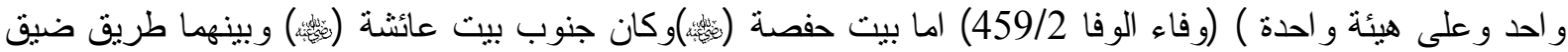

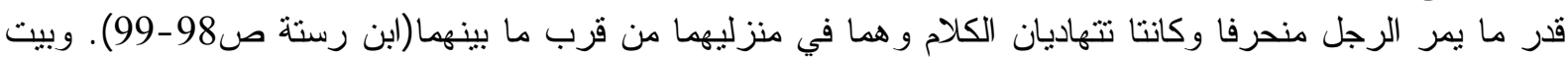

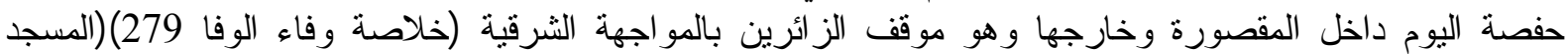

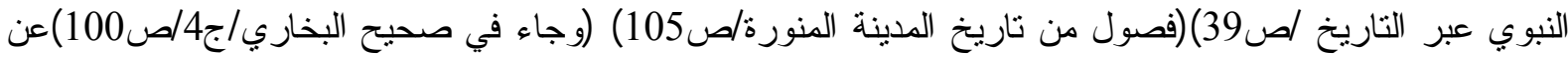

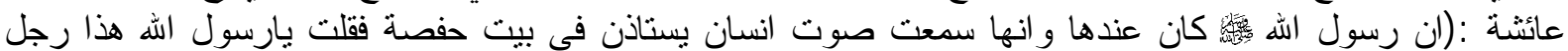

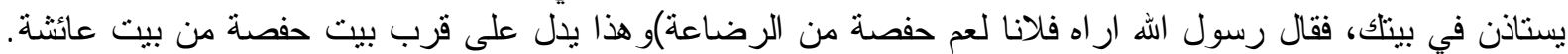
(يحدث أبو هريرة وهو من أهل الصفة-انه كان يغشى عليه من الجوع فيما بين بين بيت عائشة وأم أم سلمة)(المدينة المنورة/ص) وقد وردة ورد ان حجرة أم سلمة كانت في الجهة الثرقية من حجرة فاطمة و إنها كانت مطلة على الطريق

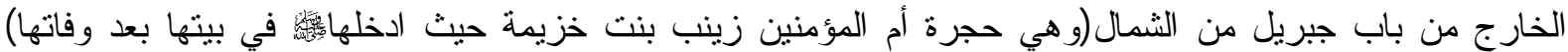

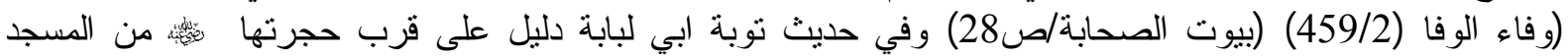

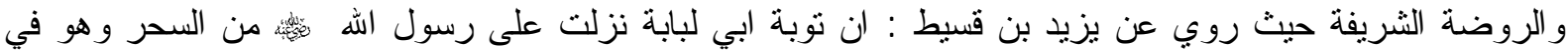

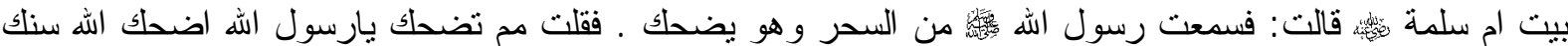

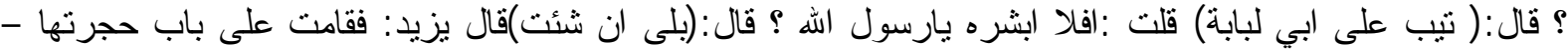

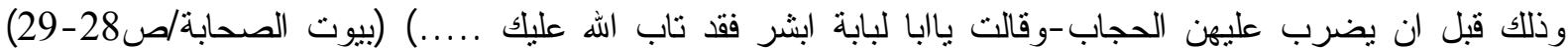

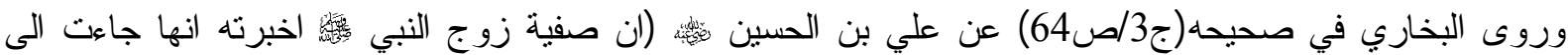

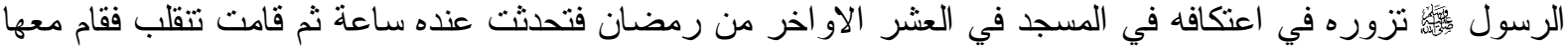

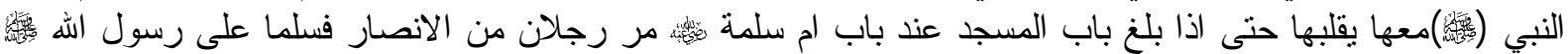

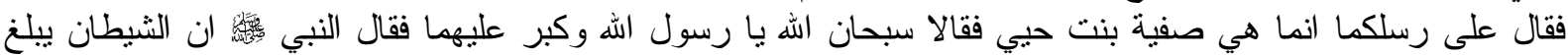

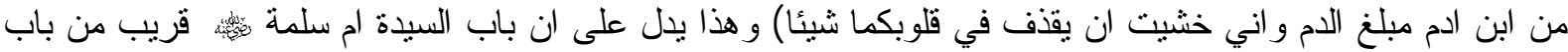

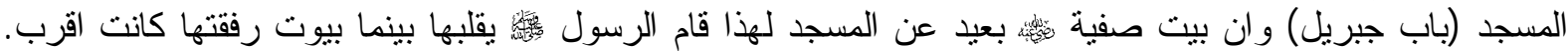




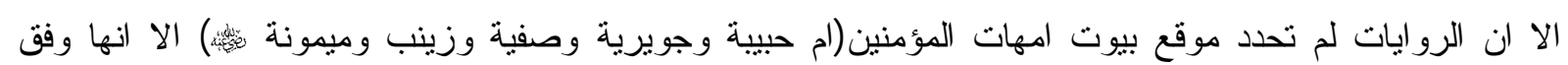

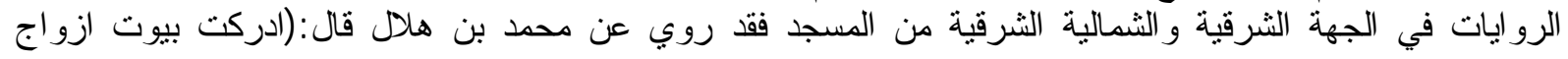

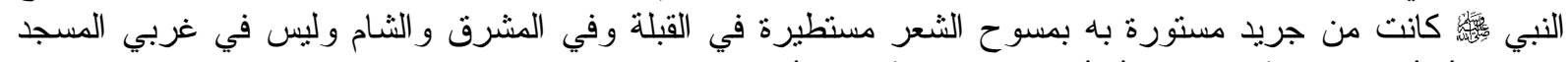

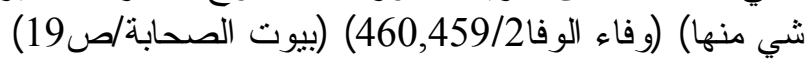

: 3 - 1 -

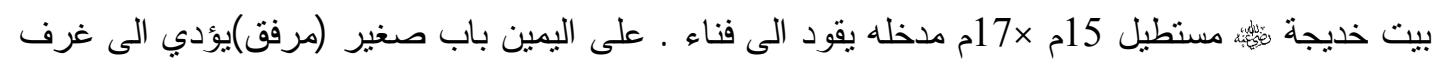

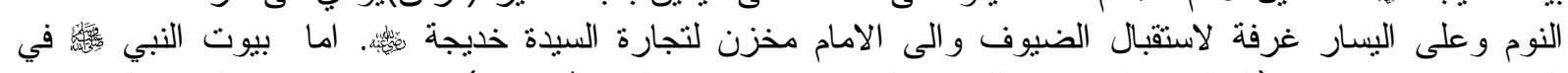

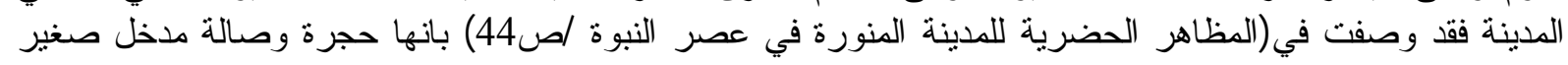

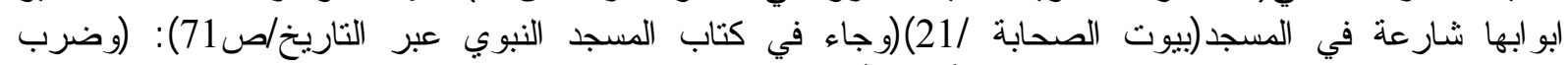

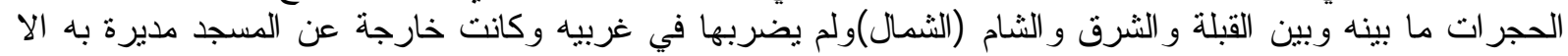

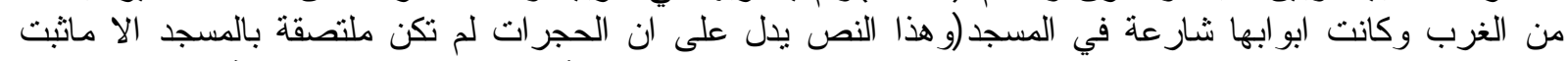

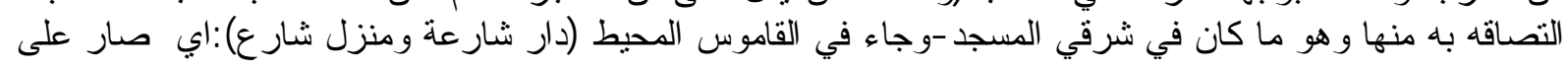

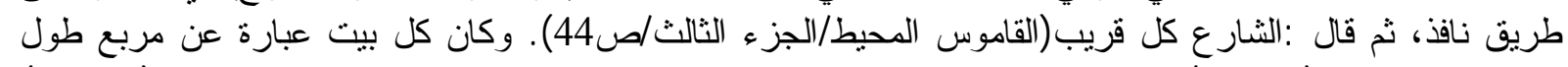

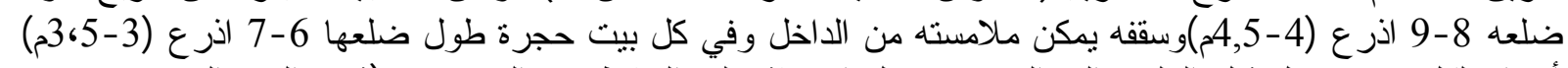

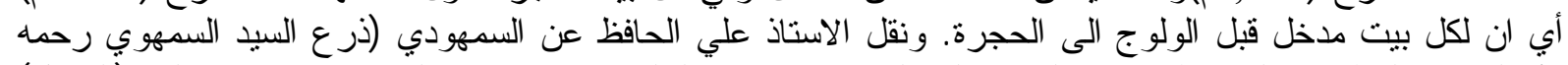

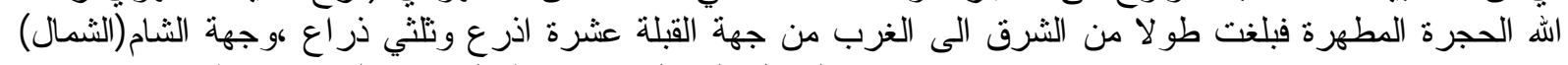

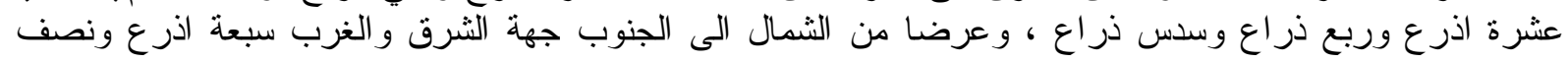

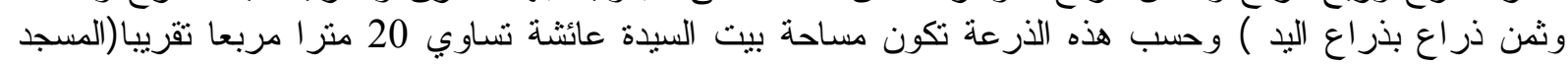

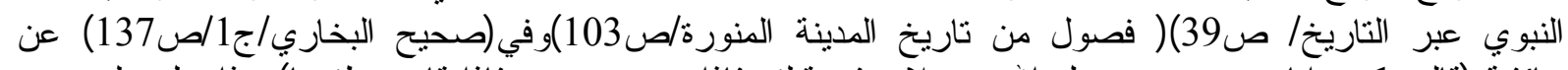

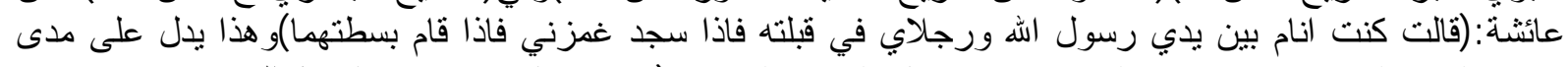

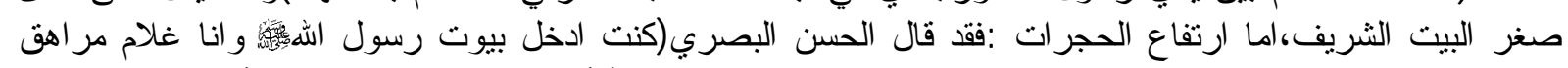

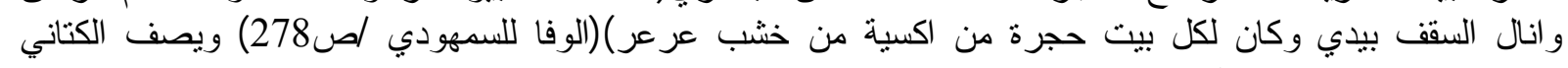

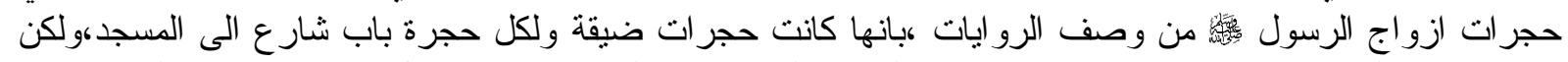

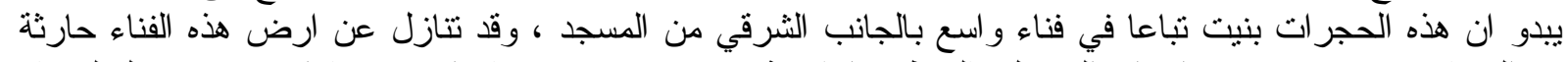

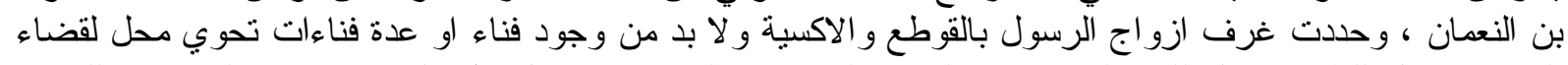

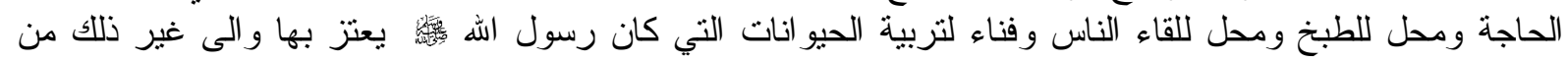

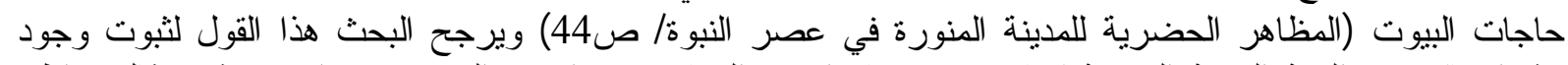

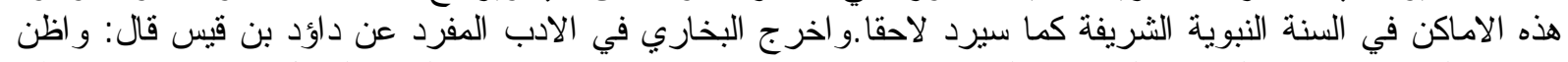

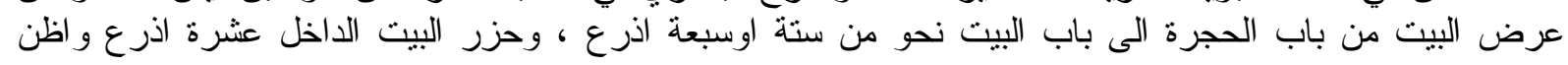

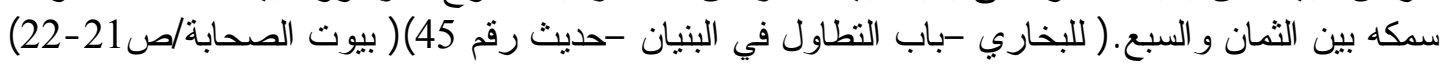

\section{3-1-3 -مكونات البيوت :}

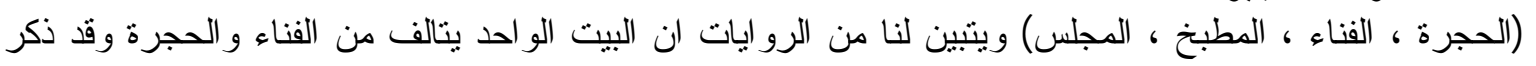

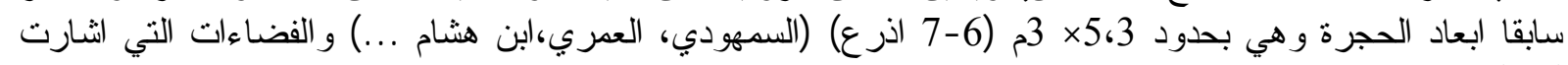

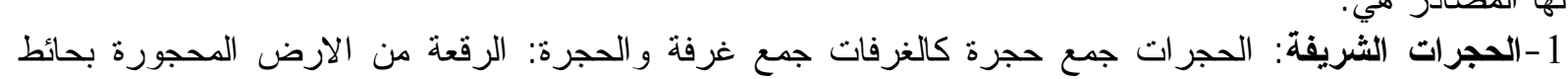

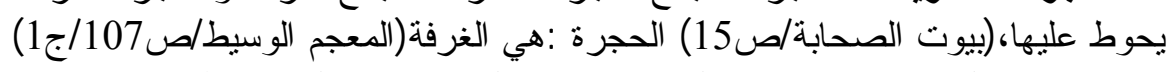

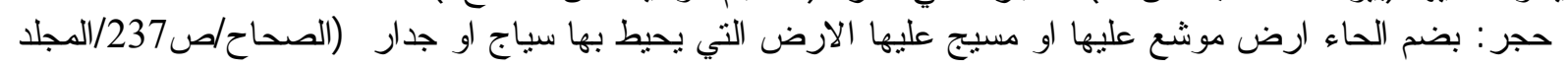

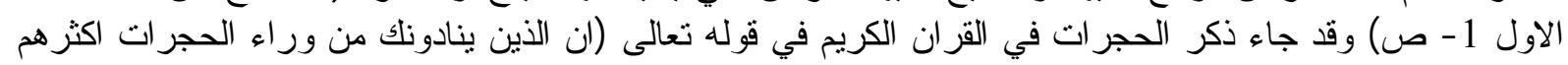

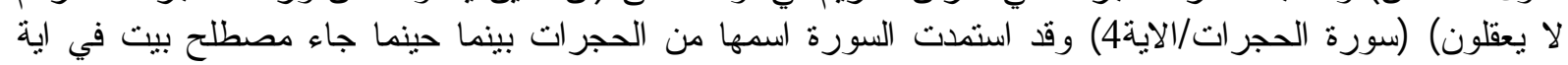

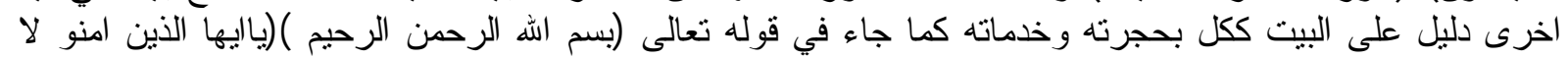

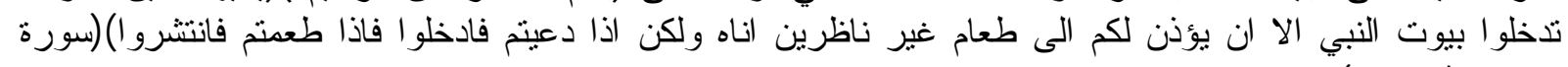

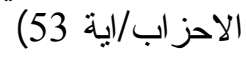

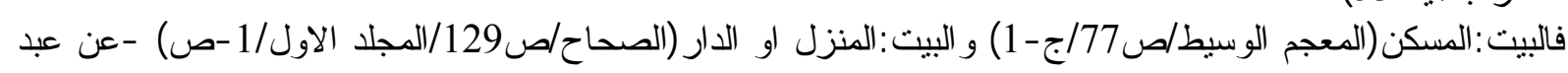

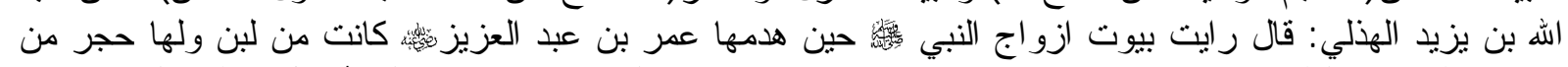

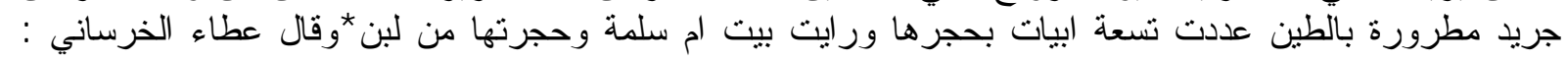




\section{$\begin{array}{llll}\text { Al-Rafidain Engineering } & \text { Vol.18 } & \text { No.2 } & \text { April } 2010\end{array}$}

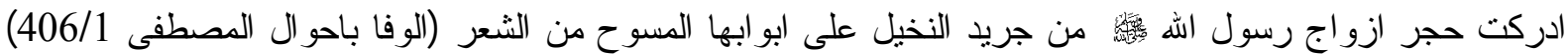

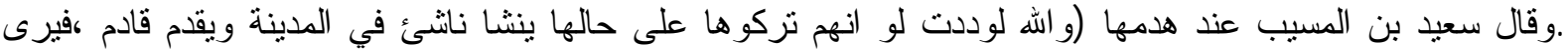

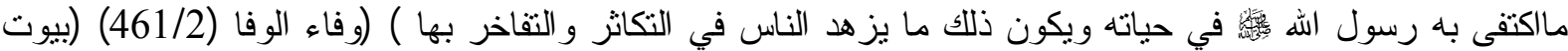

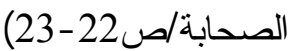

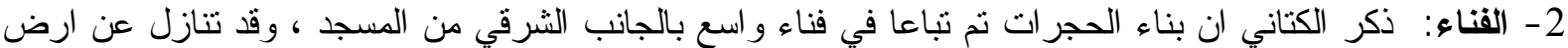

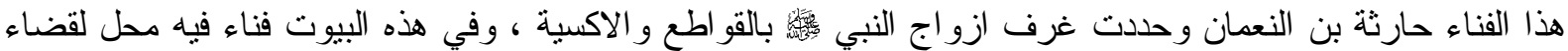

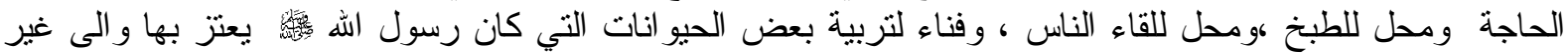

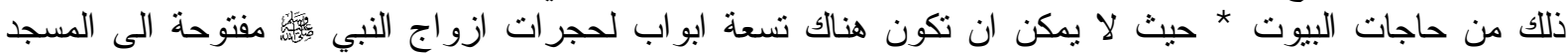

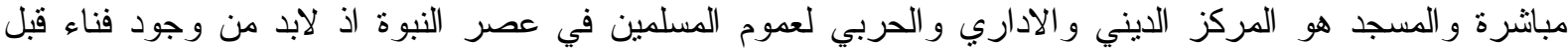

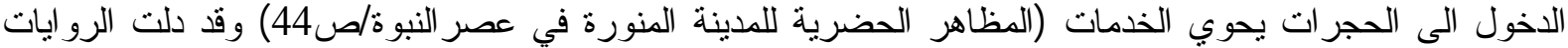

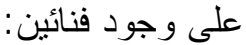

| 2 -الفناء الخاص بكل بيث ويحوي فضاءات للخدمة هي:

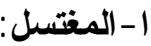

يبدو ان البيت الذي يستحم فيه كان يسمى المغتسل ويكون موجود ضمن فناء البيت الخاص فالرو اية تخبر بان

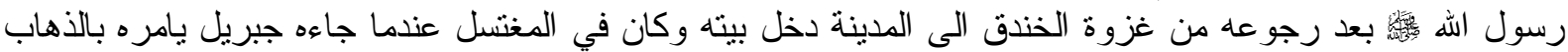

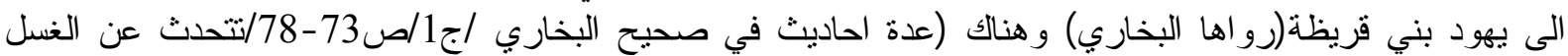

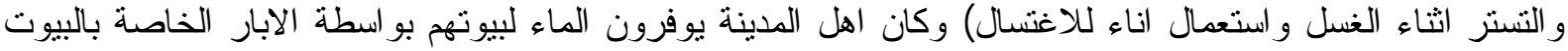
و التي دعى الرسول ب - مكان للطبخ ومكان للجلوس(مجلس):

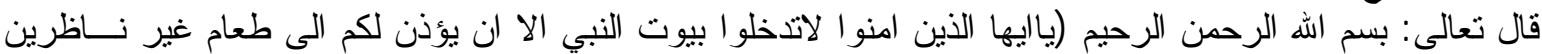

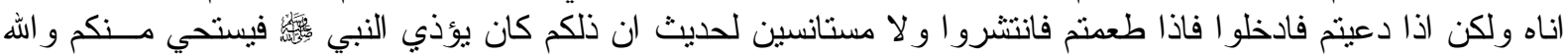

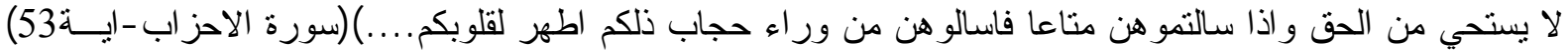

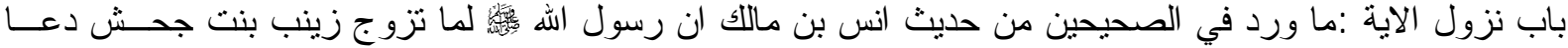

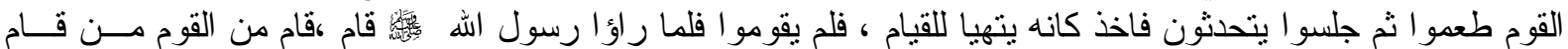

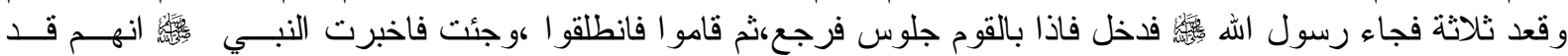

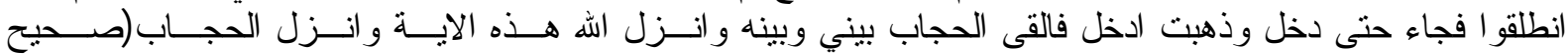

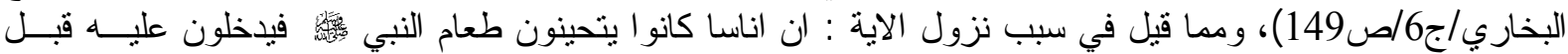

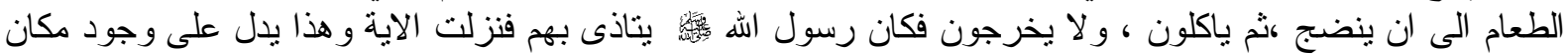

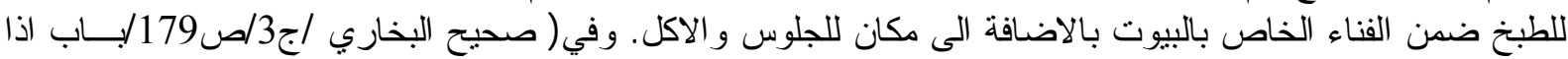

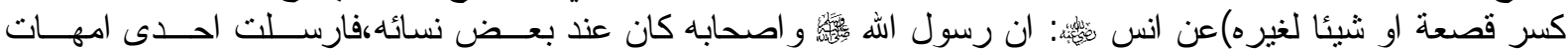

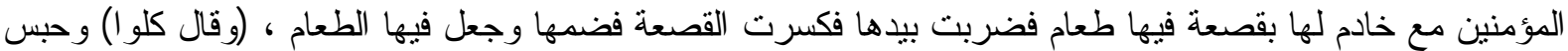

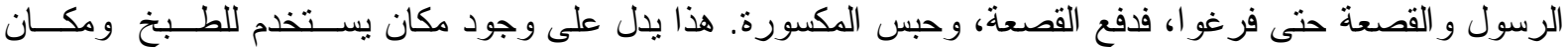

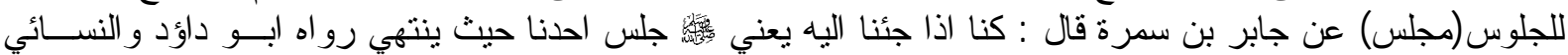

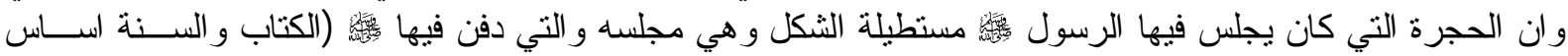

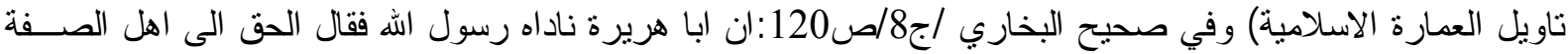

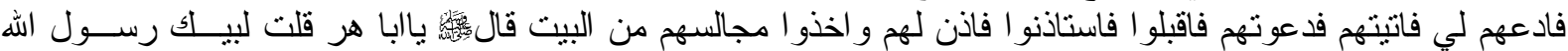

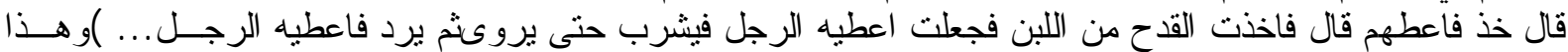

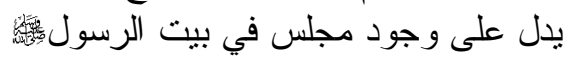

\section{2-2 - 20ناء عام مشترك بين البيوت ويحوي فضاعات مشتركة منهيا:}

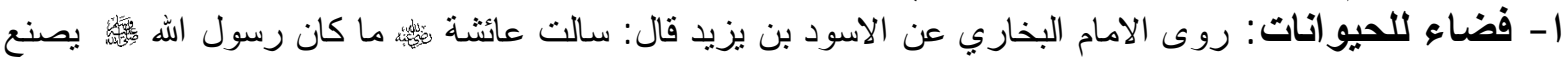

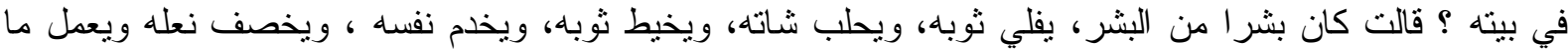

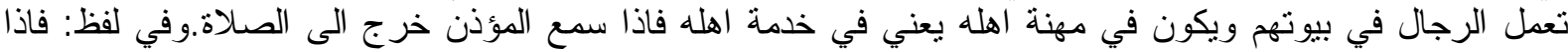

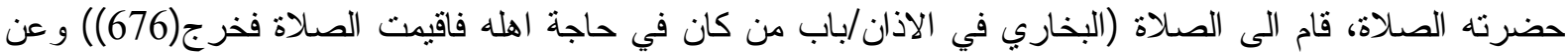

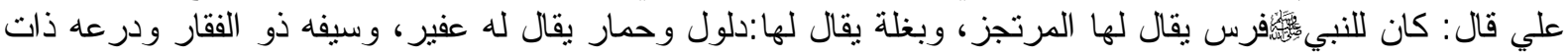

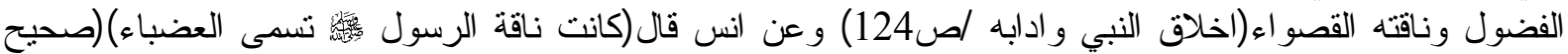


البخاري /ج8/صاص130)وعن ابي بن عباس ابن سهل عن ابيه عن جده قال( كان للنبي في حائطنا فرس يقال لها

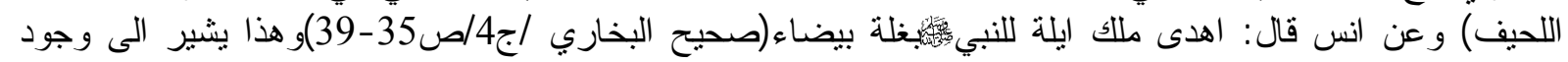

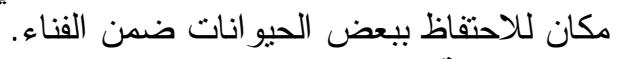
ب - المشربة:

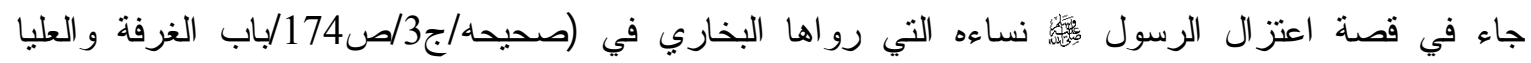
المشرفة وغير المشرفة في السطوح) ان رسول الله

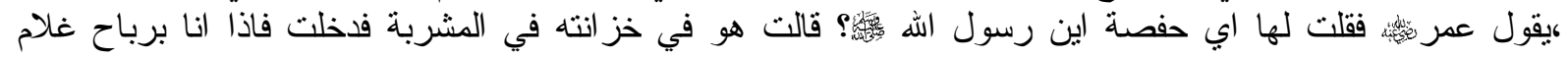

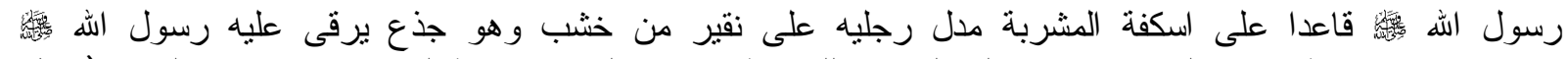

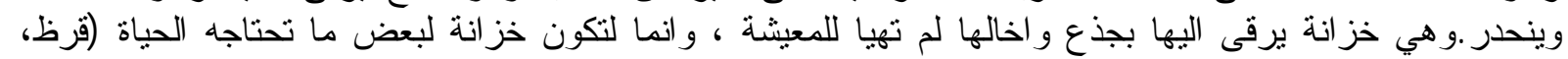

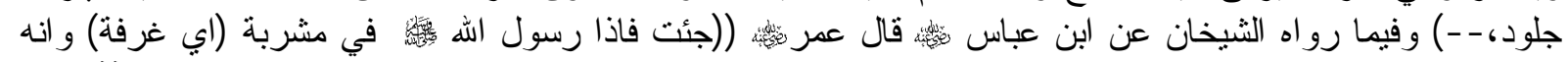

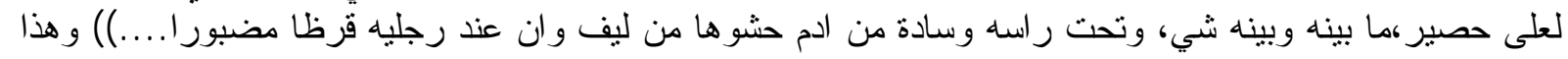

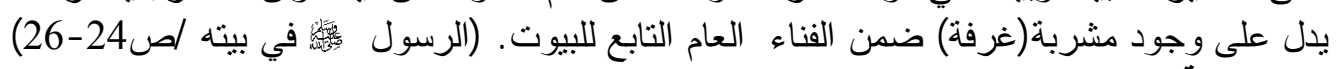
ج - الخيمة : كان ملحقا بالبيوت النبوية بالفناء خيمة (خباء) من سعف ، و وجاء ذللك فيما رو اه الطبر اني من معاجمه الثلاثة و ابو

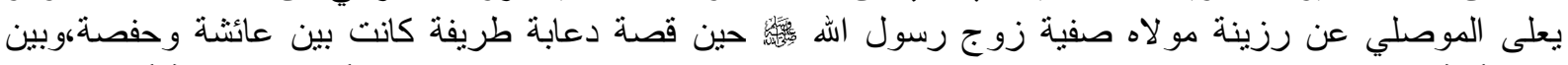

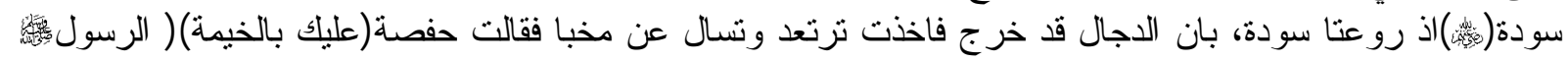

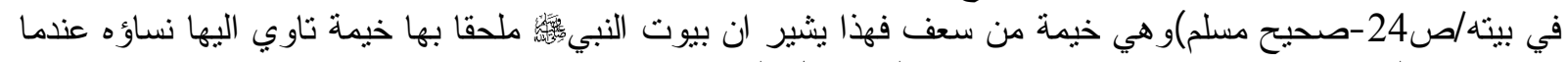
يكون عنده الصحابه وربما كانت تشع بعض من متاع البيت منل الرحى.

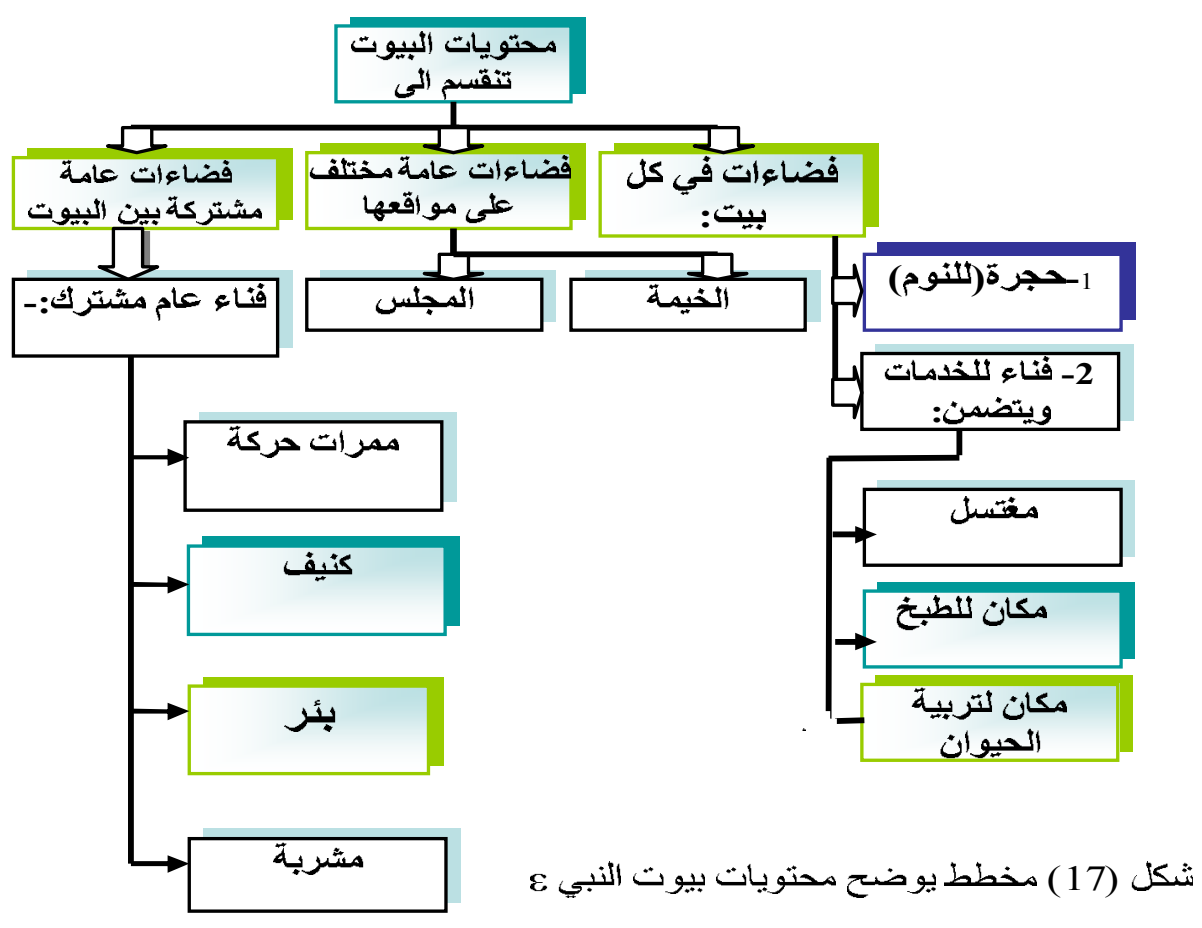

دـ - الكنيف:

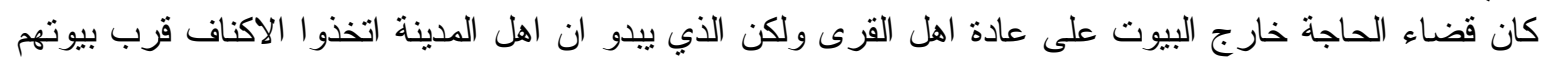

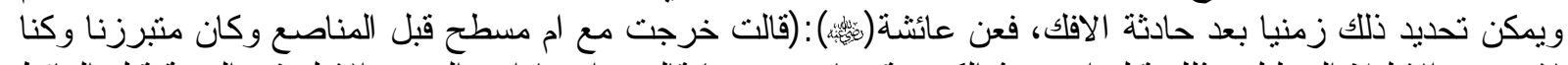

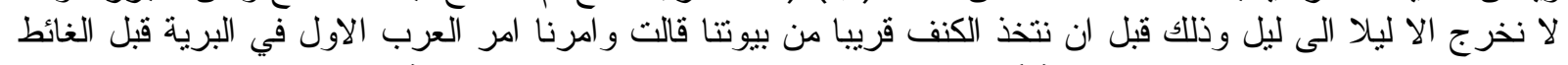

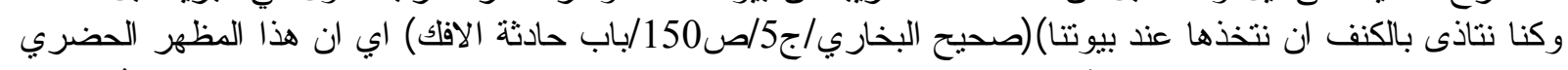

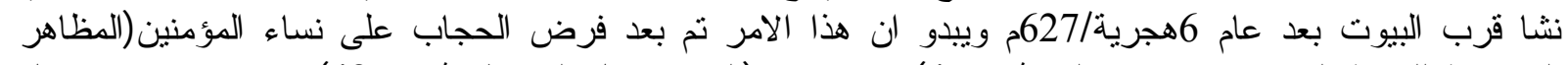

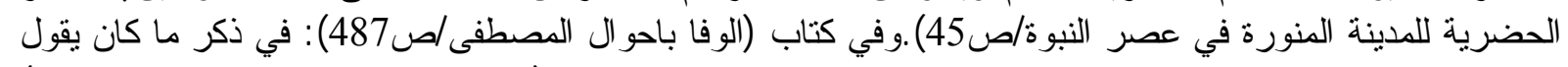

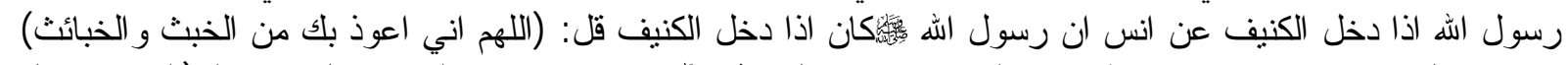

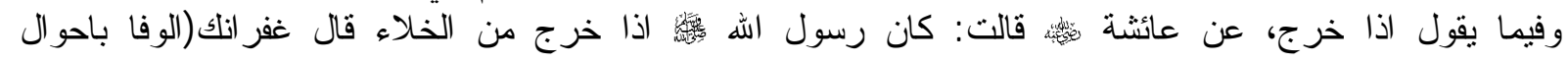


المصطفى/487) (هذا دليل على وجود الكنيف)وعن عائشة قالت :دخلت المخرج جوف الليل فجرى بينها وبين

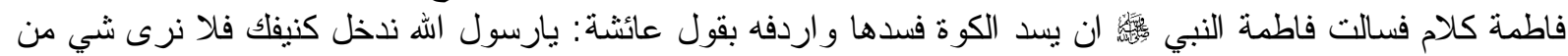

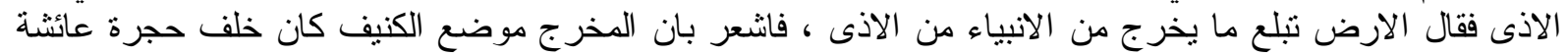

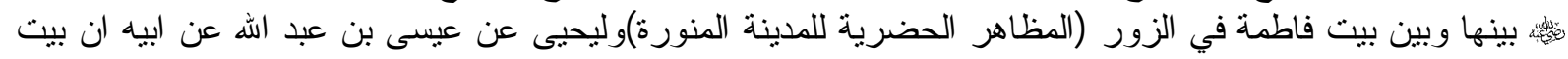

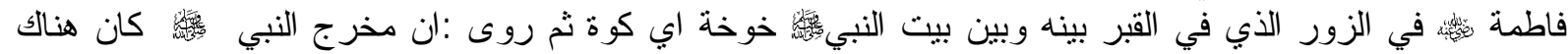

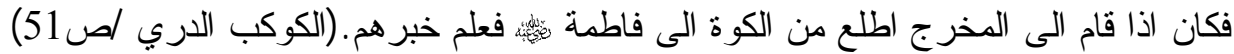

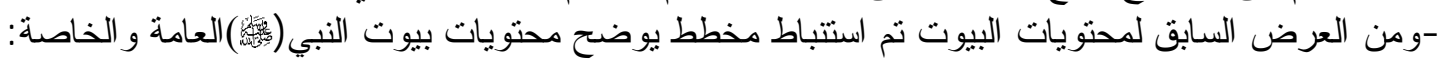

\section{2-3 - 2-3 - 20ناقشة التصور ات:}

ان التصور ات السابقة بشكل عام لم ترسم بمقياس صحيح فاعطت صورة غير و اضحة عن حجم ومساحة وموقع

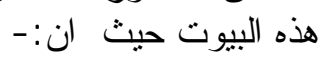

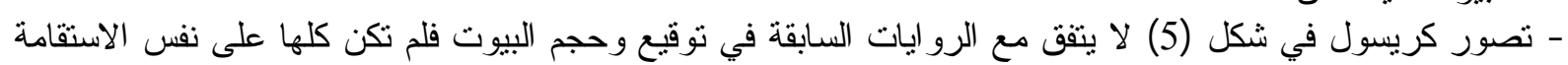

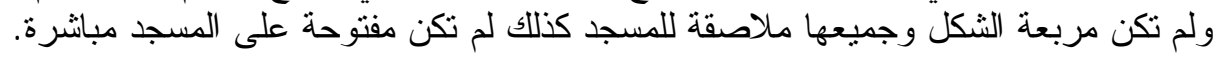
- ايضا نلاحظ في تصور محمود عكوش شكل رقم (6) لانئ ينقق مع الروايات في الحجم و التوقيع لاكثر البيوت اضافة

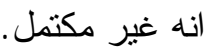
- اما في تصور المهندس عبد الرحيم الخولي في شكل (7) يوجد خطا في حجرة ام سلمة هي حجرة زينب بنت الته خزيمة

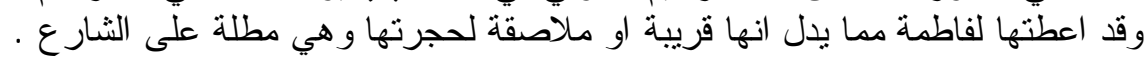

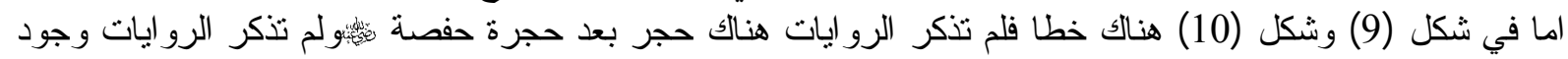

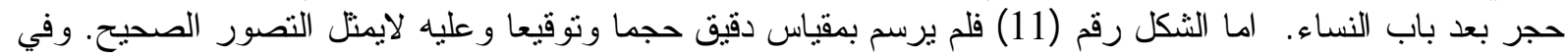

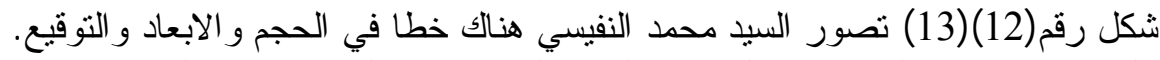
ولم تتضمن جميع التصور ات الخدمات العامة التي انثارت اليها الادبيات التاريخية.

\section{3-3 -وضع التصور الإنتر اضيي:}

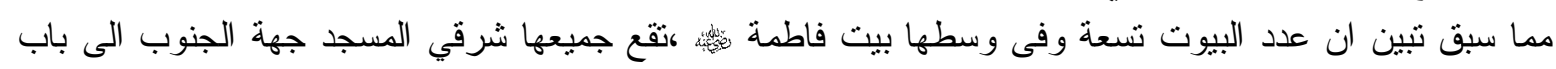

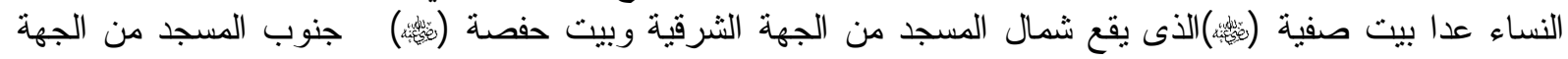

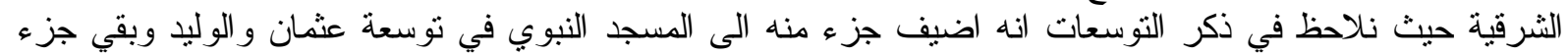

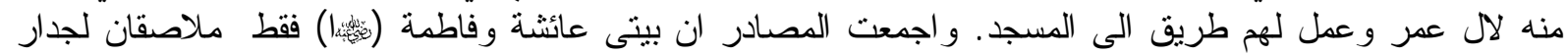

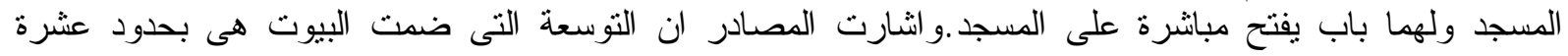

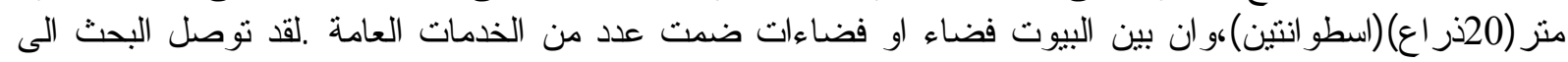

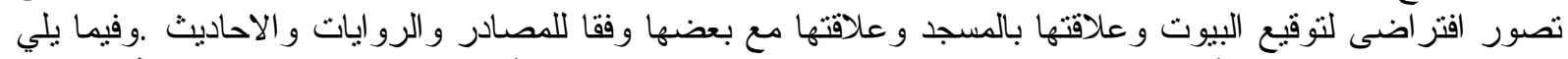

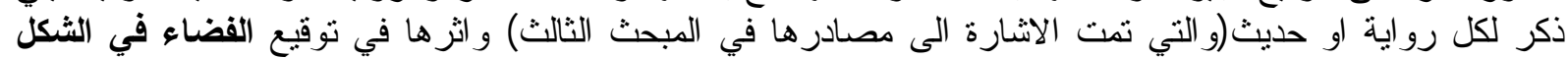

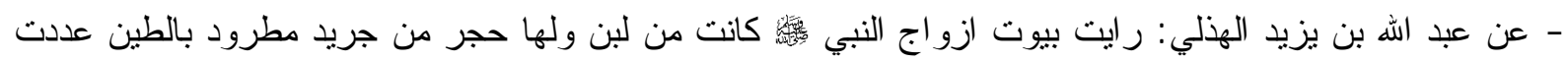

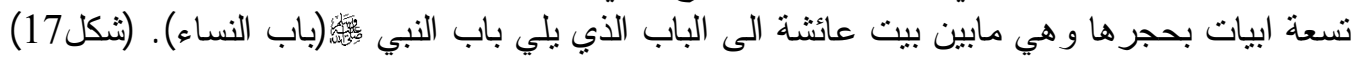

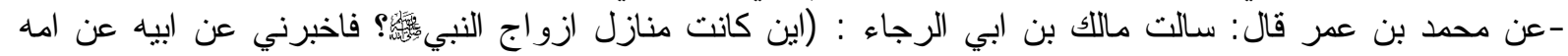

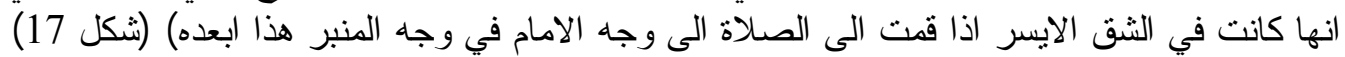

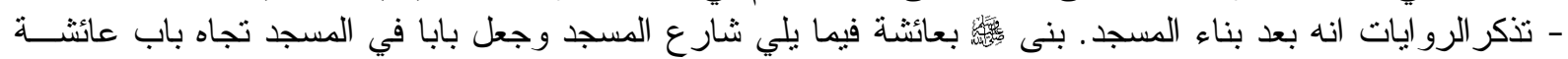

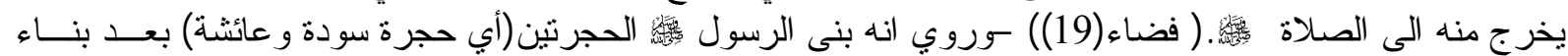

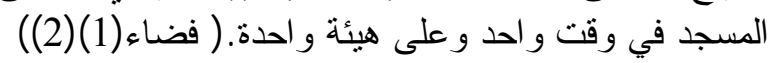

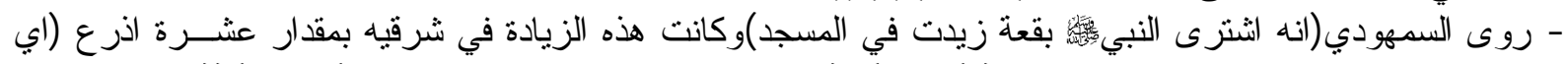

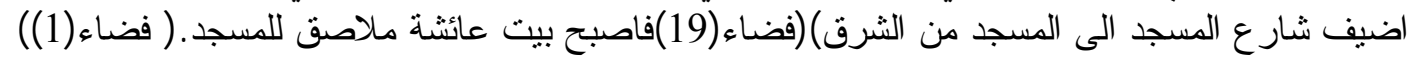

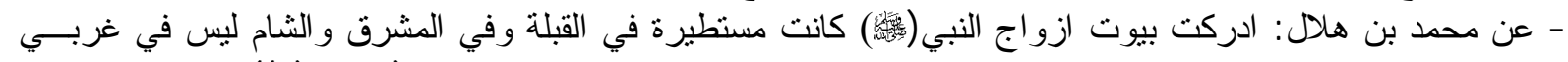

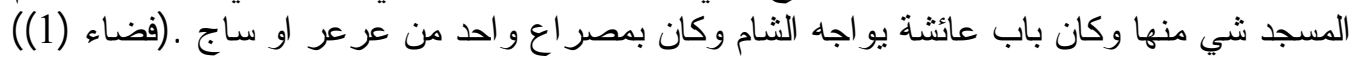

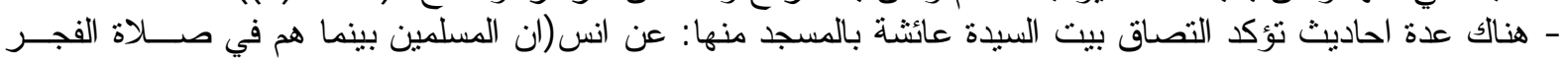

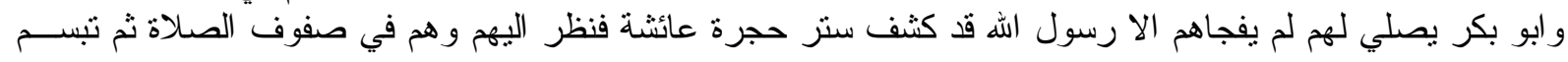


يضحك..)وعن عائثة:(انها كانت نرجل تعني راس رسول الله

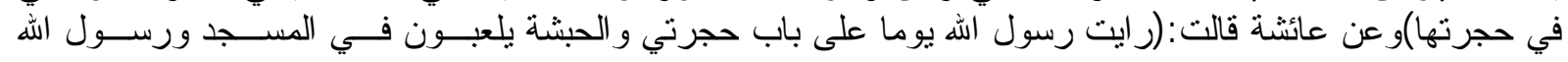

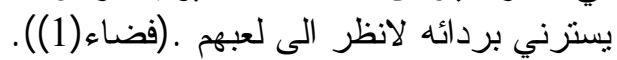

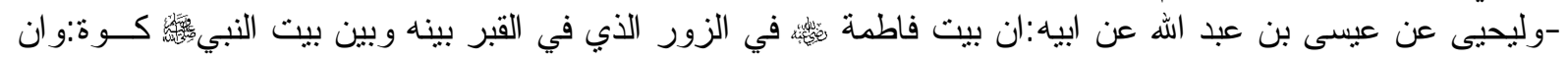

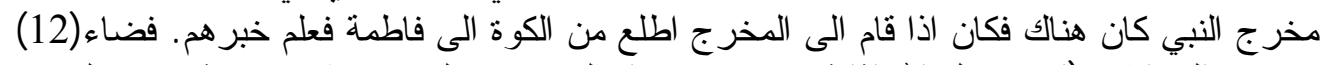

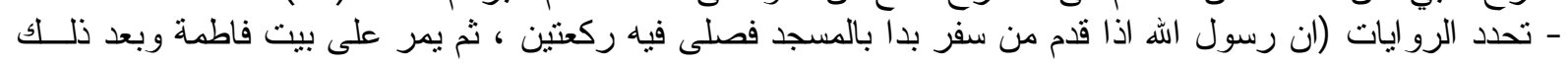

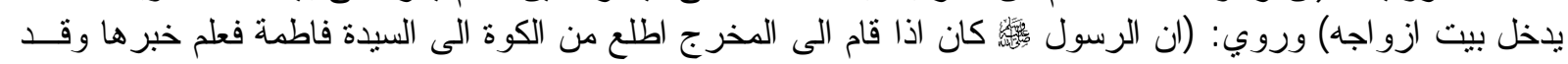

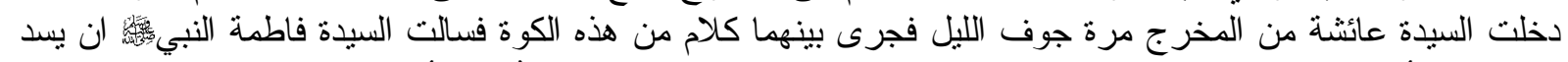

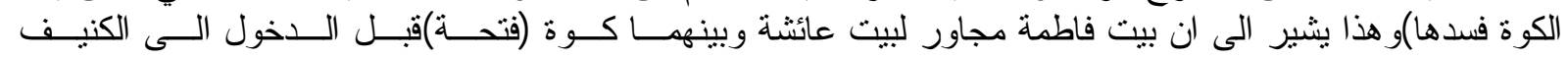

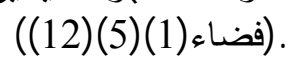

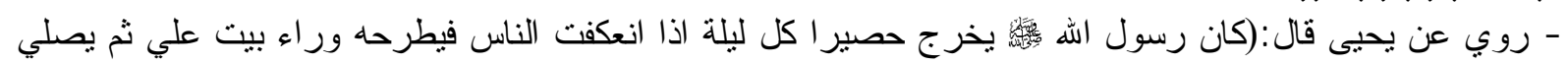

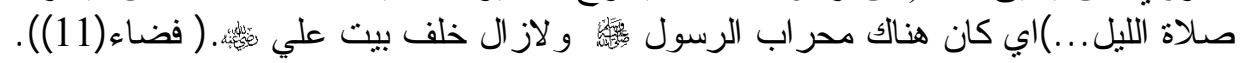

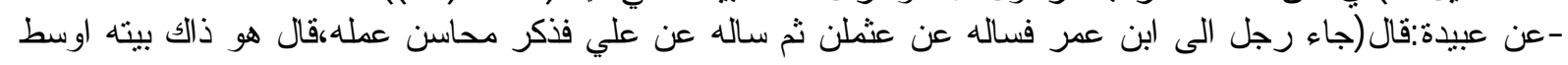

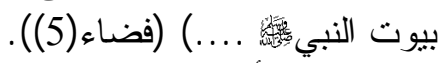

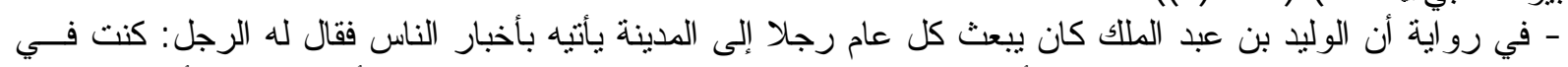

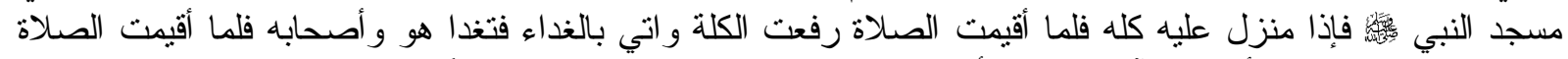

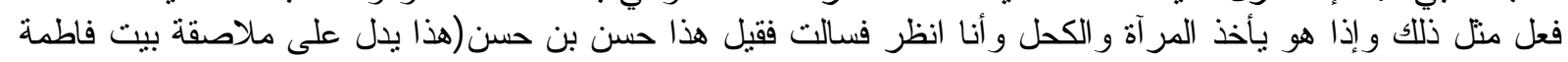

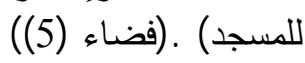

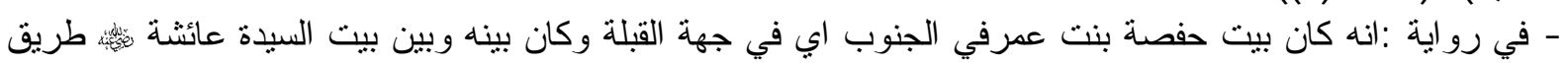

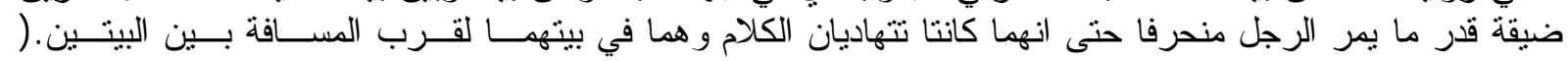

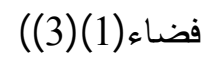

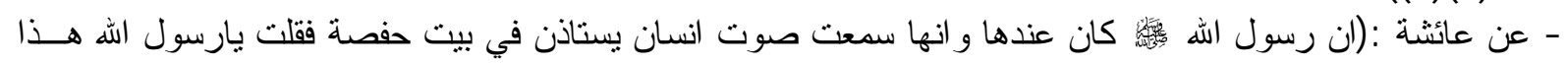

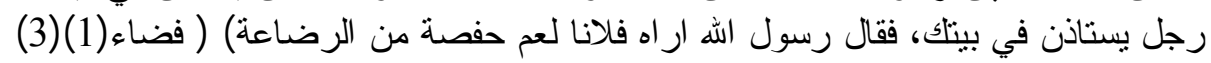

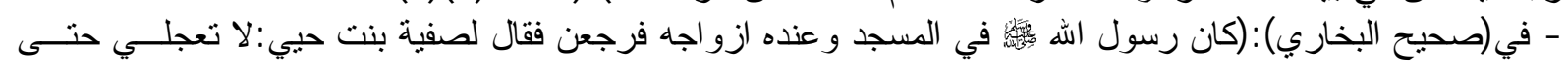

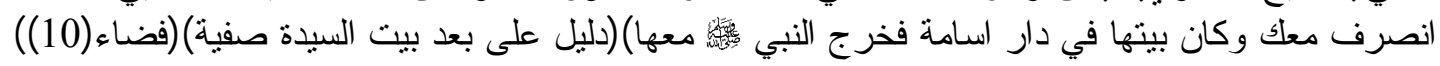

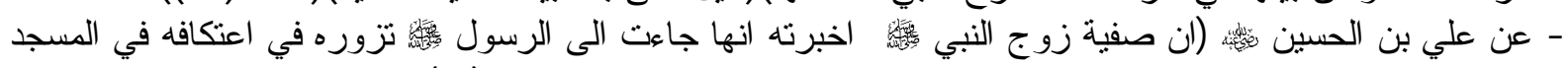

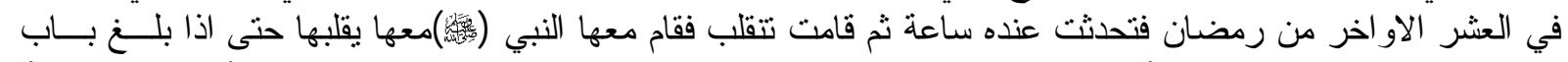

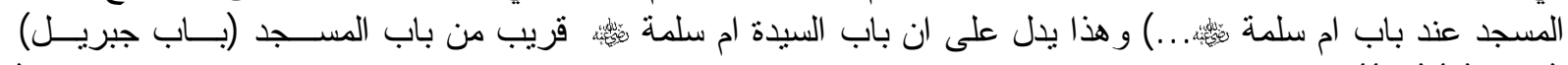

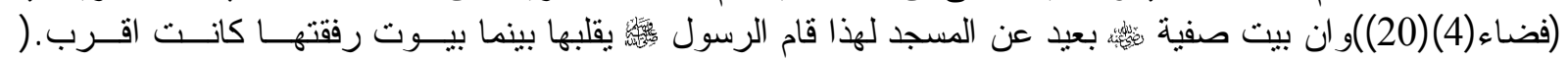

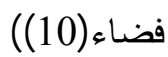
-(يحدث أبو هريرة وهو من أهل الصفة-انه كان يغشى عليه من الجوع فيما بين بيت عائشة وأم سلمة) وهذا يدل على (210)

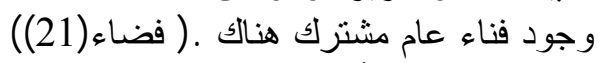

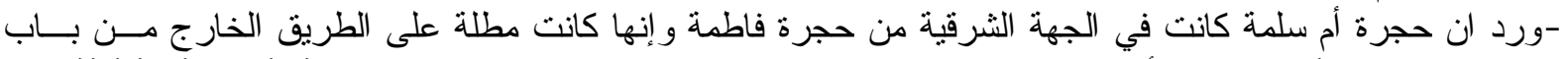

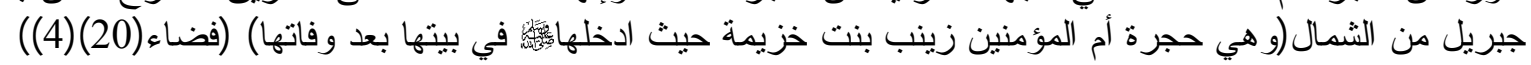

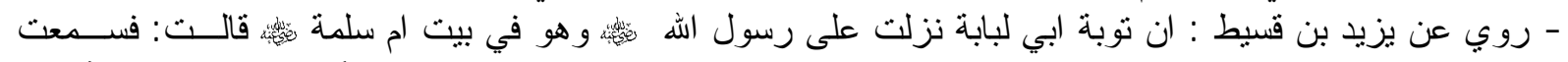

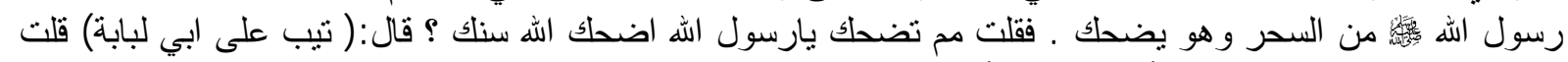

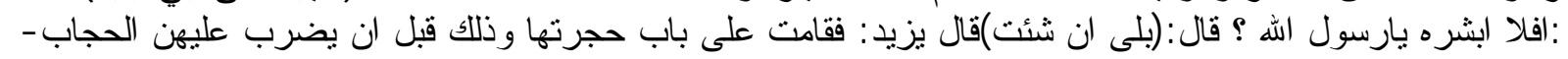

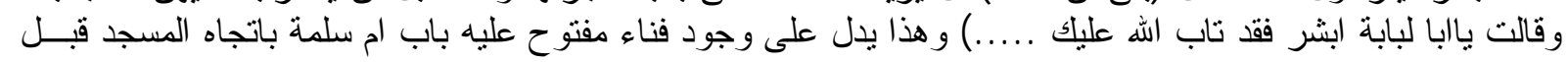

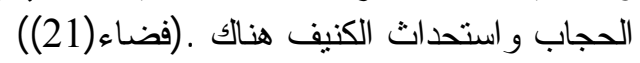

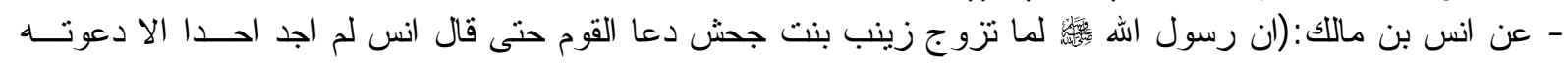

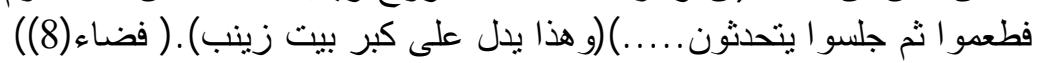

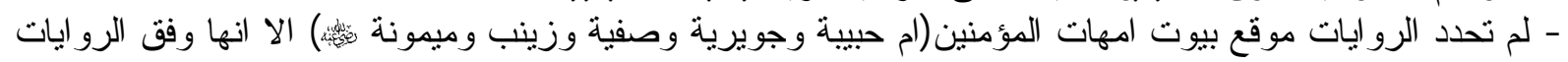

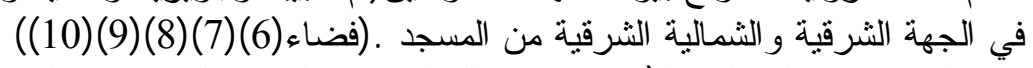

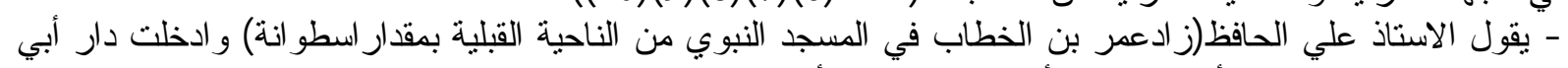

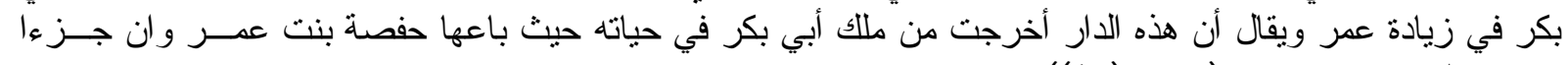

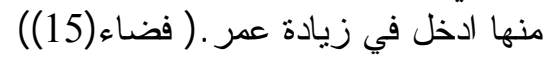
- قال ابن النجار :(زادعثمان من القبلة -الجنوب -الى موضع الجدار اليوم بمقدار اسطوانة). (فضاء(16)) 
- روى ابن زبالة انه :(لما احتيج الى بيت حفصة في زيادة عثمان قالت: فكيف بطريقي الى المسجد ؟ فقال لها نعطيك

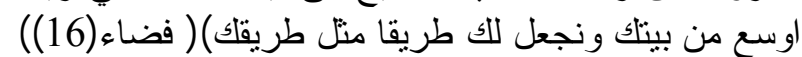

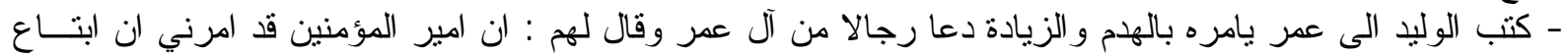

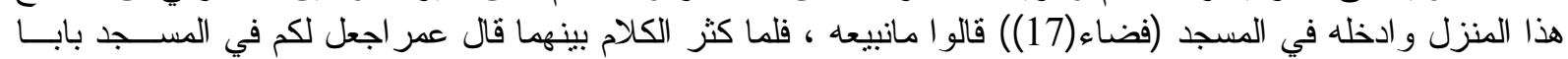

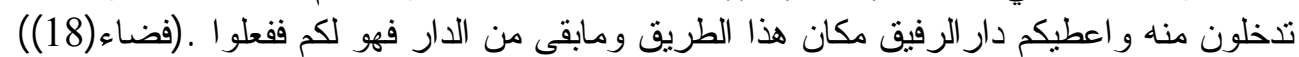

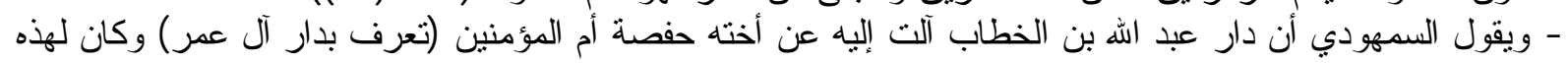
الدار نفق يصلها بالمسجد .( فضاء (17)(18)(

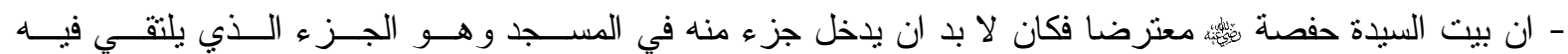

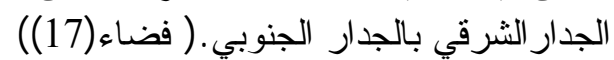

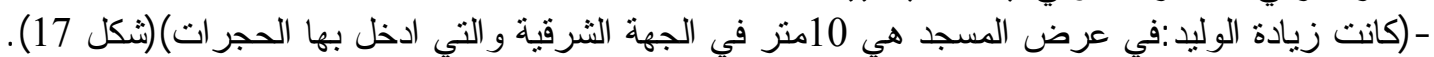

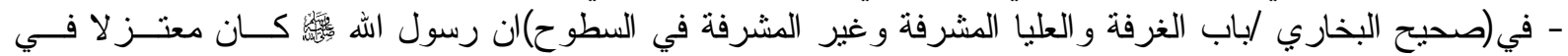

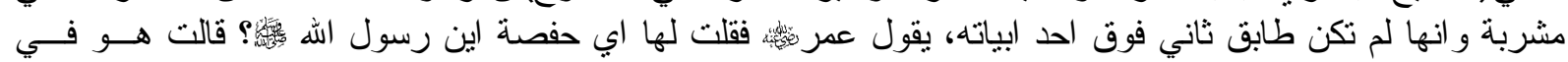

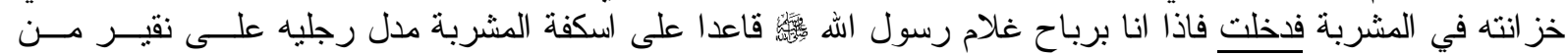

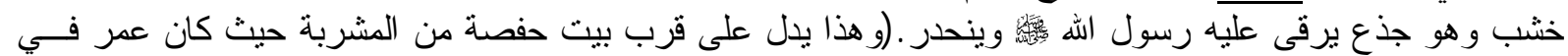

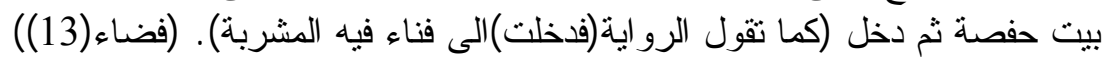

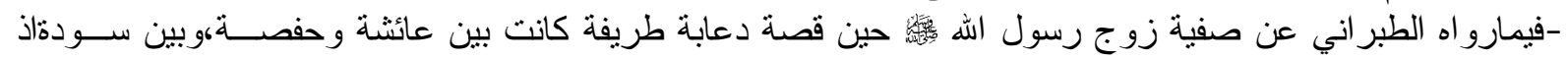

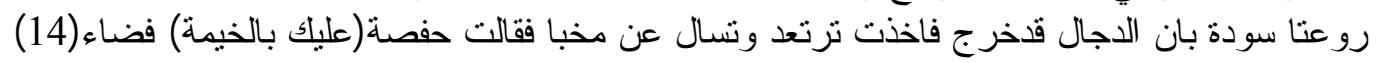

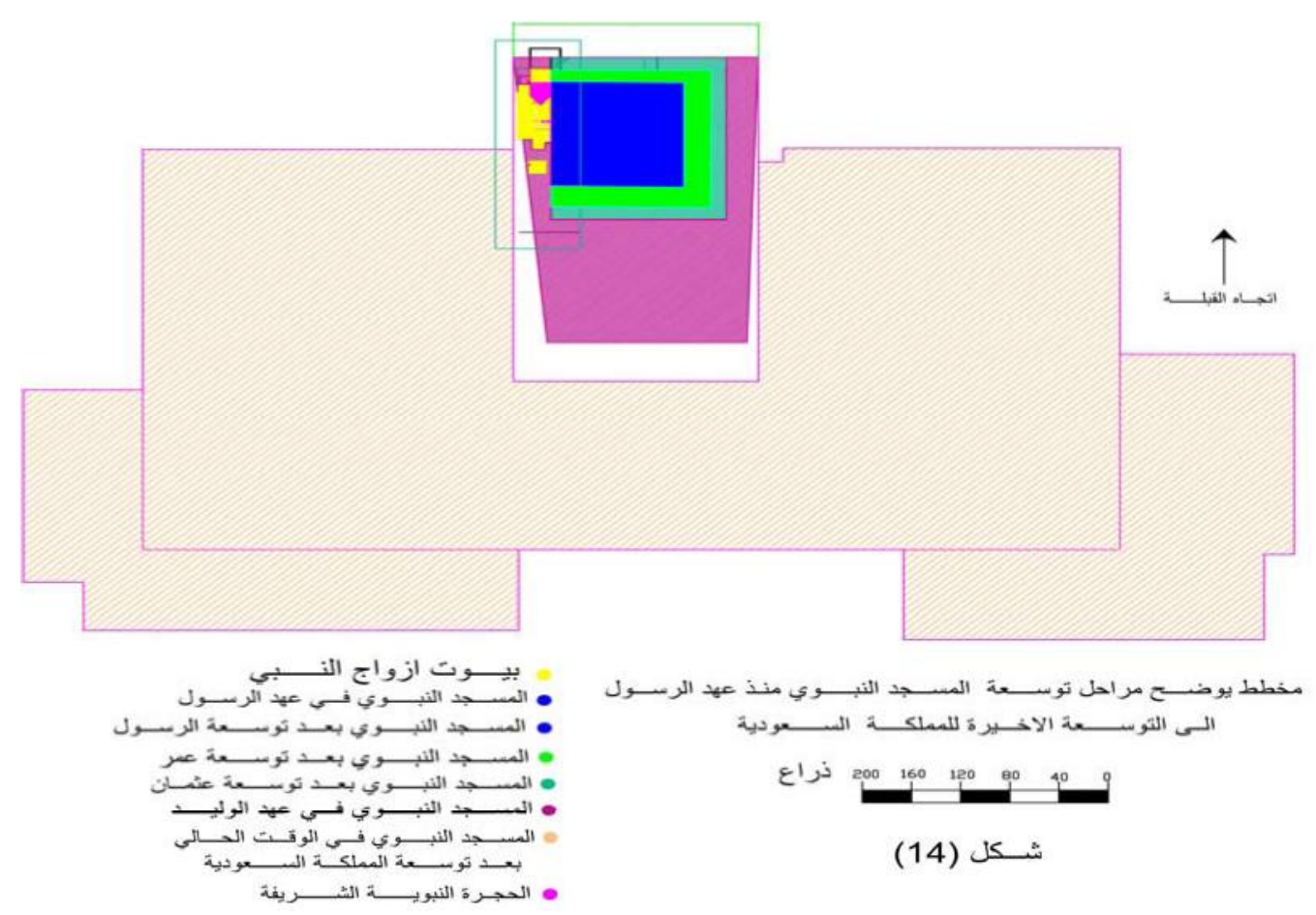


العمري: بيوت الرسول ( صلى الله عليه وسلم ) ثاني ابداع في العمارة الاسلامية
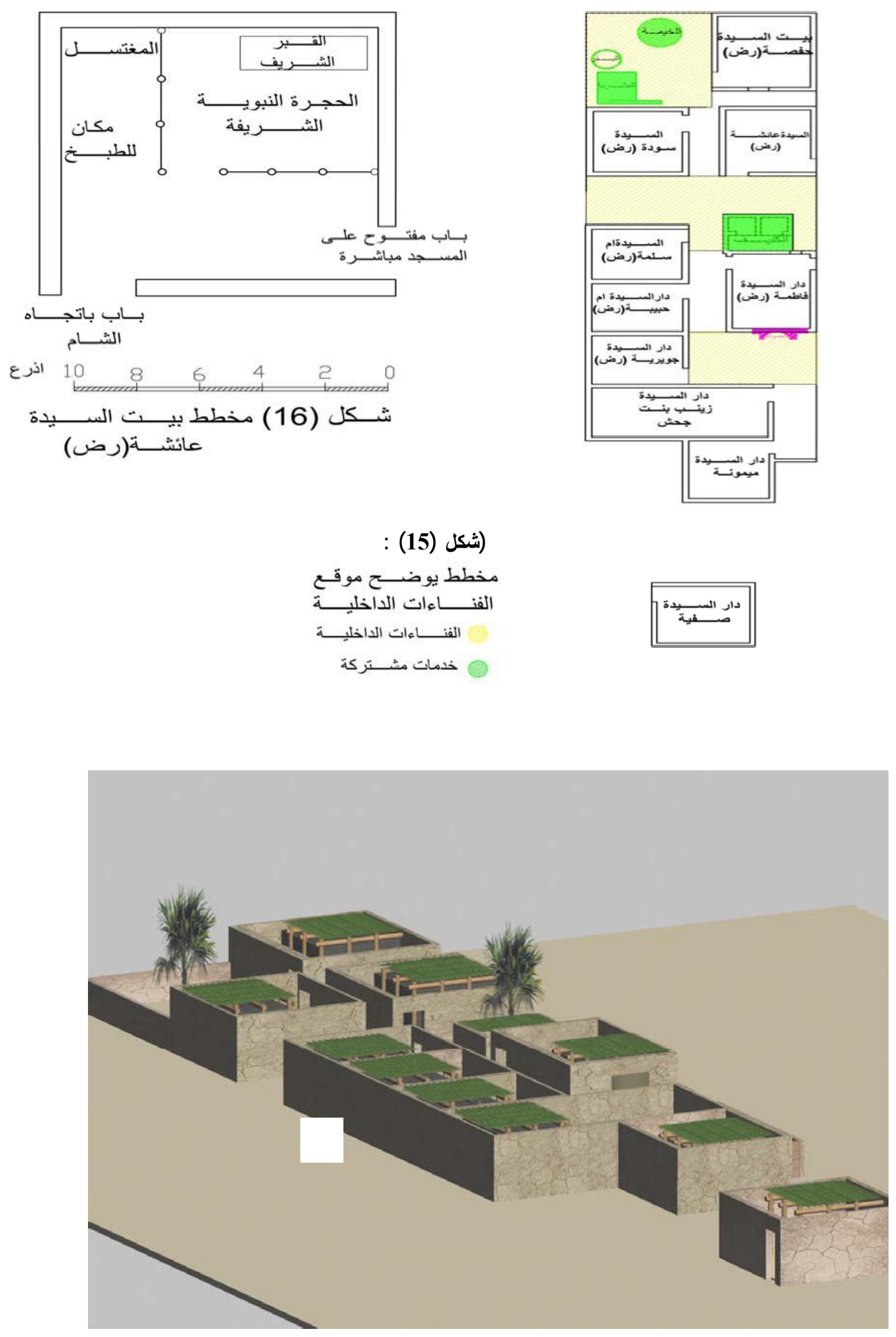


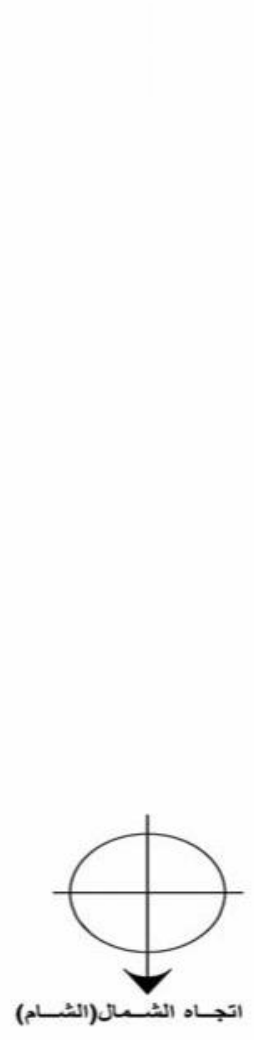

شكل (16): منظور يوضح بيوت النبي(ص)من الخارج
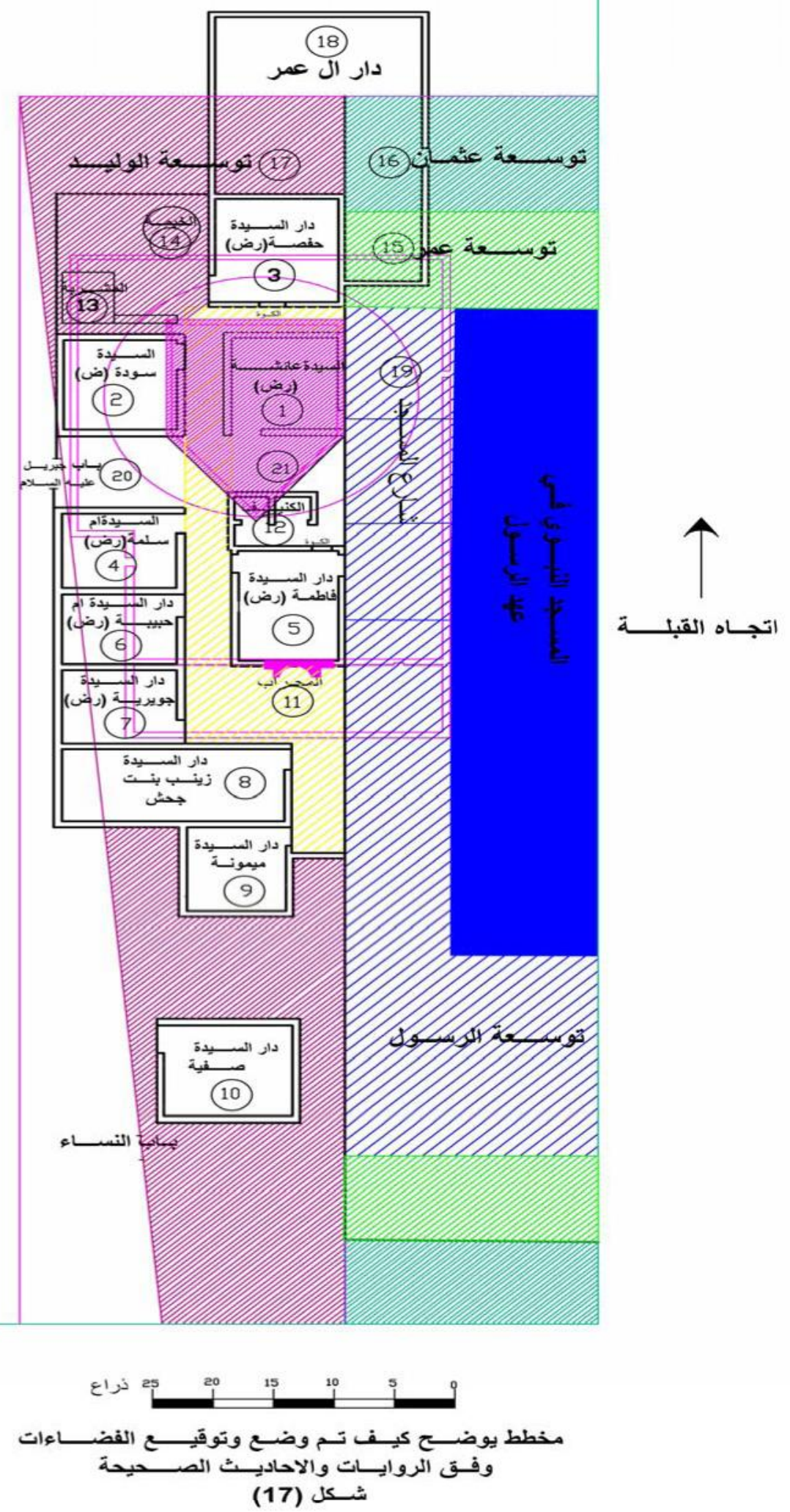


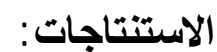

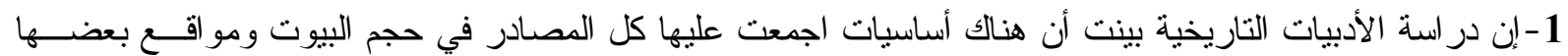

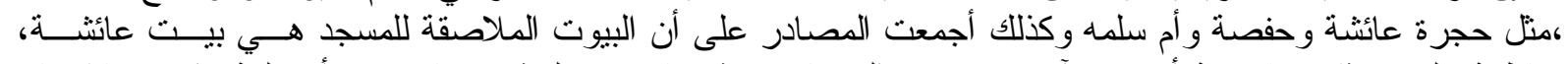

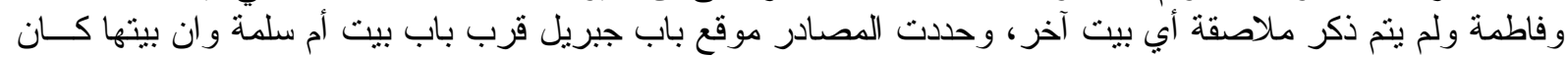

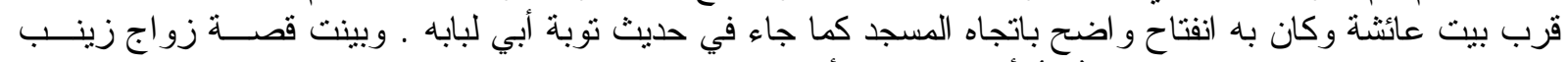

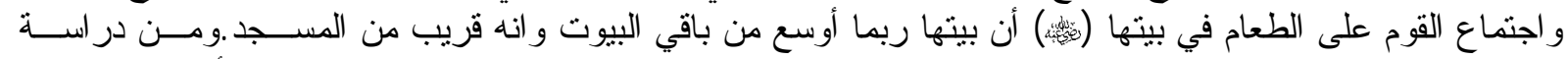

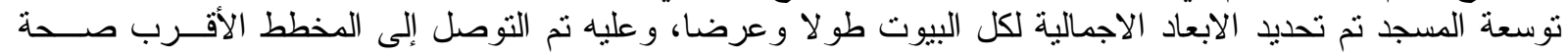

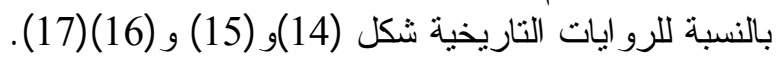

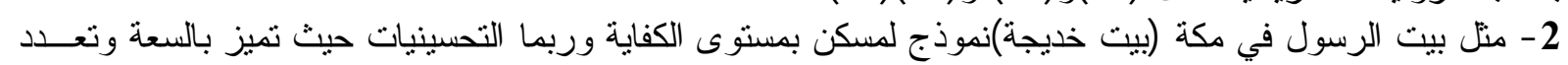

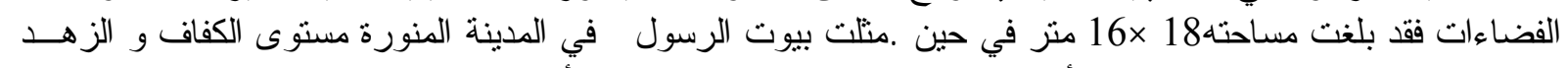

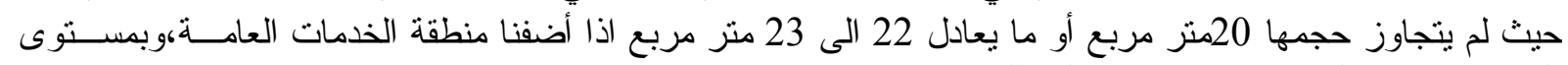
الحد الادنى من المساحات مع تحقيق المتطلبات الانسانية و الاجتماعية.

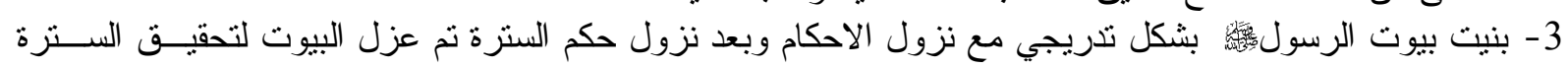

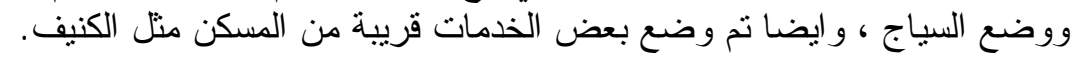

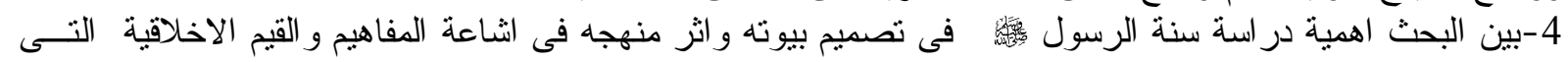

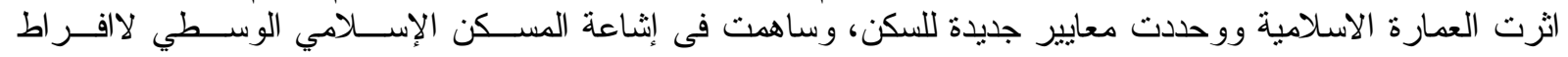
و لاتفريط الترت

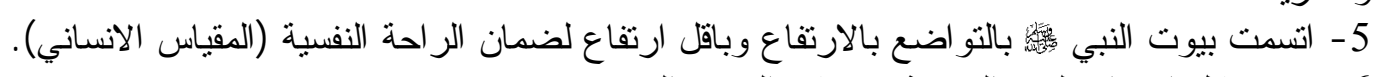

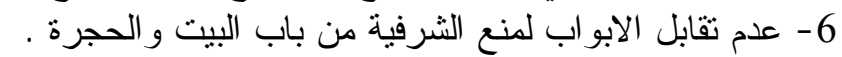

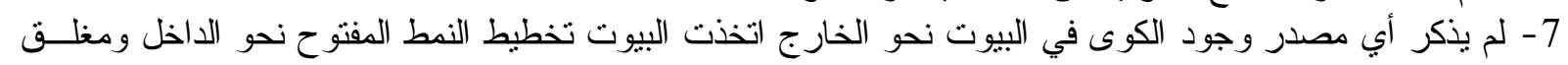

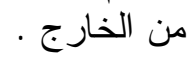
8 - كان قرار الرسول

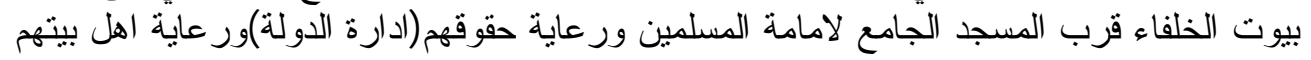

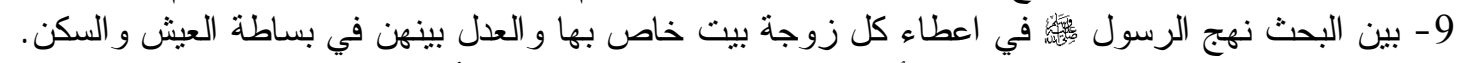

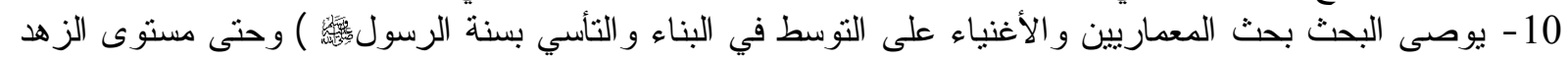
الذي اختاره الرسول البحت

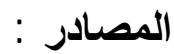

1 -ابن النجار/الامام الحافظ ابي عبد الله محمد بن محمود بن النجار البغدادي/الدرة الثمينة في اخبار المدينة .

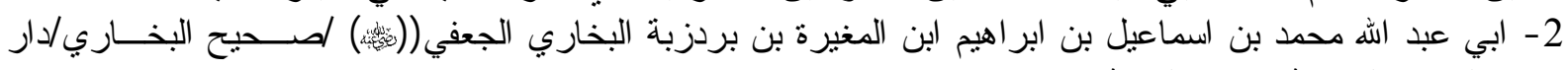

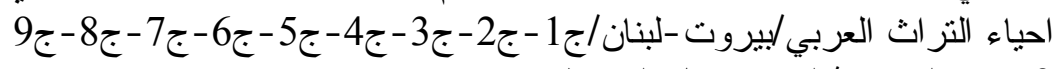

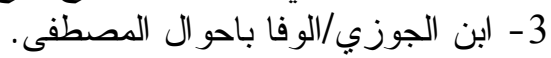

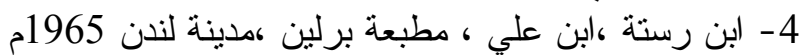

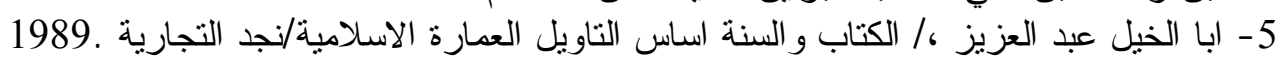

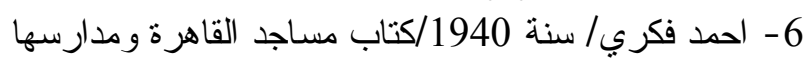

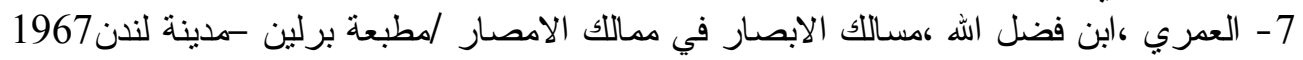
8 - الاصبهاني /اخلاق النبي و ادابه.

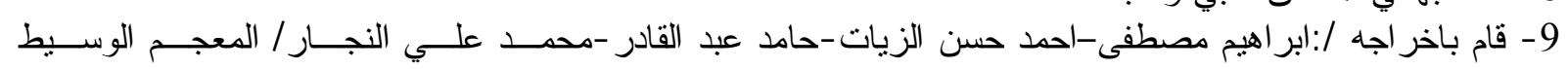

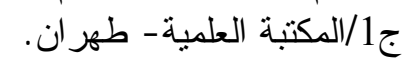

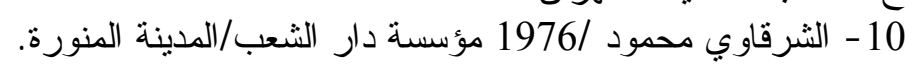

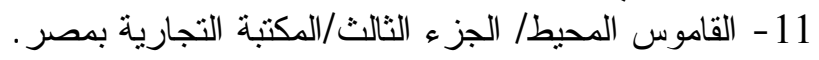

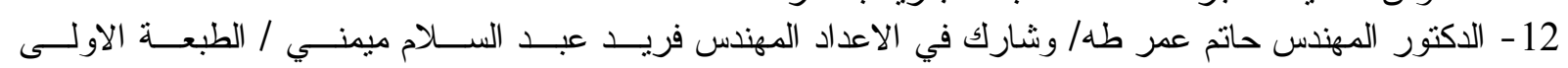

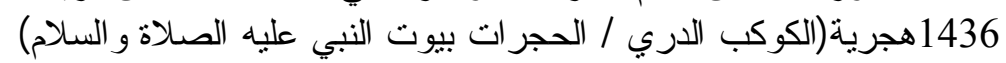

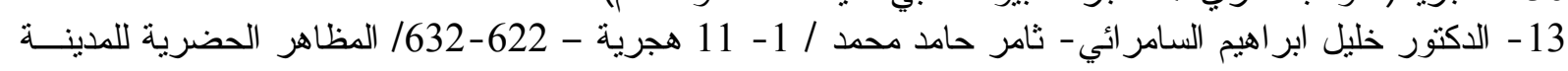

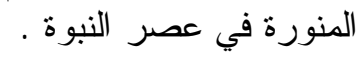


14 - علي حافظ/ شركة المدينة المنورة للطباعة و النشر / جدة المملكة العربية السعودية/فصول مــن تــاريخ المدينــة

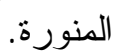

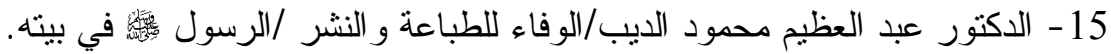

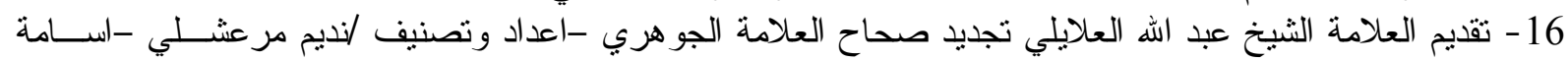

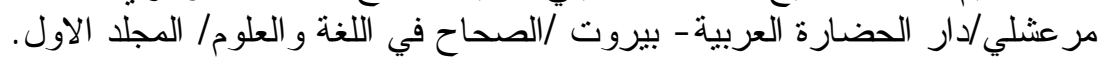

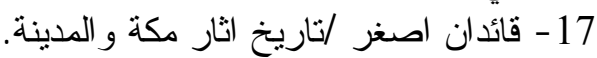

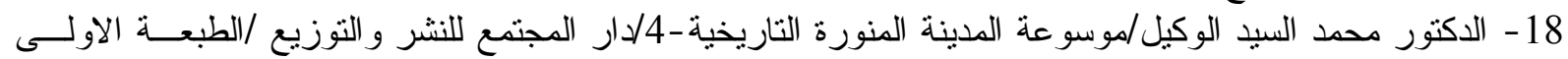
1409هجرية -1988 - 1988 م / المسجد النبوري النبوس عبر التاريخ.

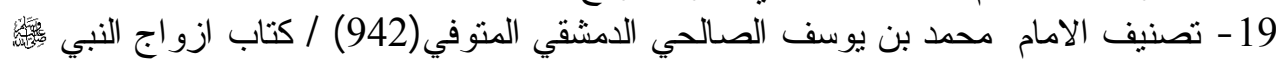

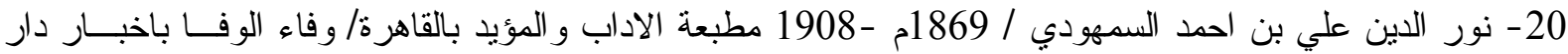
المصطفى. 